\title{
Effectiveness of Quaternary Ammonium in Reducing Microbial Load on Eggs
}

\author{
Hao Yuan Chan ${ }^{1}$, Anis Shobirin Meor Hussin ${ }^{1,2, * \mathbb{D}}$, Nurul Hawa Ahmad ${ }^{1}$, Yaya Rukayadi ${ }^{1}(\mathbb{D}$ and \\ Abd-ElAziem Farouk ${ }^{3}$ \\ 1 Faculty of Food Science and Technology, University Putra Malaysia, Serdang 43400, Malaysia; \\ samuel.tfa@gmail.com (H.Y.C.); nurulhawa@upm.edu (N.H.A.); yaya_rukayadi@upm.edu.my (Y.R.) \\ 2 Halal Products Research Institutes, University Putra Malaysia, Serdang 43400, Malaysia \\ 3 Department of Biotechnology, College of Science, Taif University, P.O. Box 11099, Taif 21944, Saudi Arabia; \\ farouk@tu.edu.sa \\ * Correspondence: shobirin@upm.edu.my
}

check for updates

Citation: Chan, H.Y.; Meor Hussin, A.S.; Ahmad, N.H.; Rukayadi, Y.; Farouk, A.-E. Effectiveness of Quaternary Ammonium in Reducing Microbial Load on Eggs. Molecules 2021, 26, 5259. https://doi.org/ $10.3390 /$ molecules 26175259

Academic Editor: Warren McNabb

Received: 24 June 2021

Accepted: 20 July 2021

Published: 30 August 2021

Publisher's Note: MDPI stays neutral with regard to jurisdictional claims in published maps and institutional affiliations.

Copyright: (c) 2021 by the authors. Licensee MDPI, Basel, Switzerland. This article is an open access article distributed under the terms and conditions of the Creative Commons Attribution (CC BY) license (https:// creativecommons.org/licenses/by/ $4.0 /)$.

\begin{abstract}
Table eggs are an affordable yet nutritious protein source for humans. Unfortunately, eggs are a vector for bacteria that could cause foodborne illness. This study aimed to investigate the effectiveness of a quaternary ammonium compound (quat) sanitizer against aerobic mesophilic bacteria, yeast, and mold load on the eggshell surface of free-range and commercial farms and the post-treatment effect on microbial load during storage. Total aerobic mesophilic bacteria, yeast, and molds were enumerated using plate count techniques. The efficacy of the quaternary ammonium sanitizer (quat) was tested using two levels: full factorial with two replicates for corner points, factor A (maximum: 200 ppm, minimum: 100 ppm) and factor B (maximum: 15 min, minimum: $5 \mathrm{~min})$. Quat sanitizer significantly $(p<0.05)$ reduced approximately $4 \log 10 \mathrm{CFU} / \mathrm{cm}^{2}$ of the aerobic mesophilic bacteria, 1.5 to $2.5 \log 10 \mathrm{CFU} / \mathrm{cm}^{2}$ of the mold population, and 1.5 to $2 \log 10 \mathrm{CFU} / \mathrm{cm}^{2}$ of the yeast population. However, there was no significant $(p \geq 0.05)$ response observed between individual factor levels (maximum and minimum), and two-way interaction terms were also not statistically significant $(p \geq 0.05)$. A low $\left(<1 \log 10 \mathrm{CFU} / \mathrm{cm}^{2}\right)$ aerobic mesophilic bacteria trend was observed when shell eggs were stored in a cold environment up to the production expiry date. No internal microbial load was observed; thus, it was postulated that washing with quat sanitizer discreetly (without physically damaging the eggshell) does not facilitate microbial penetration during storage at either room temperature or cold storage. Current study findings demonstrated that the quat sanitizer effectively reduced the microbial population on eggshells without promoting internal microbial growth.
\end{abstract}

Keywords: quaternary ammonium compound; microbial control; egg shell

\section{Introduction}

Table eggs are unequivocally the most affordable and nutritious protein source for humans [1]. In the United States alone, 7.92 billion eggs were produced in 2018, and this production number is twenty-four times the country's population of the same year [2]. Whereas, in Malaysia, the Federation of Livestock Farmers' Association of Malaysia reported that approximately 12.5 billion eggs were produced in the year 2017 with a rate of more than 6 million table eggs per day [3]. Such a substantial production and export figure is certainly in tandem with the risk of food poisoning. For example, food poisoning caused by eggs was reported in Kuala Terengganu in May 2020 [4].

Egg categorization is not only done by size but can also be categorized based on various housing systems, e.g., (i) conventional cage, (ii) barn, (iii) free-range, and (iv) organic [5]. In the conventional cage, hens are heavily loaded in a confined cage with limited movement space and lay eggs throughout their lifetime. However, a recent resurgence 
of attention to animal welfare and healthier food choices, predominantly in developed countries, has shifted interest towards free-range or organic shell eggs [6,7].

On the contrary, organic and free-range farming systems allow hens to access open-air space and improve physical activities. Nevertheless, this freedom leads to the exposure of various environmental stressors such as weather variations, predation, contact with wild birds, viral or parasitic infection, or contaminants [8,9]. Ferrante et al. [10] demonstrated that free-range and organic eggs laid on the soil/grass are more likely to be dirtier than those laid in barn and cage housing systems without contact with soil. On the contrary, Alvarez-Fernandez et al. [11] reported that free-range and organic egg aerobic bacteria contamination have no significant difference from the conventional cage housing systems. In another study, Jones et al. [12] reported that conflicting results had been reported in several research findings conducted in Europe regarding eggshell microbial contamination in different housing systems.

Numerous methods, either through thermal or nonthermal decontamination methods, have been studied. Conventional heat treatment, e.g., hot air or hot water pasteurization, is among the most promising methods [13,14]. Alongside, nonthermal microbial control, e.g., chlorine, ultraviolet light, electrolyzed oxidized water, quaternary ammonium compound (quat) sanitizer, $\mathrm{N}$-halamine, and sodium hypochlorite are also modern approaches due to their efficacy, low costing, and simple mechanism [15-18]. In a study, Wang and Slavik [19] reported a mere 3.4 and $6.7 \%$ of Salmonella enteritidis penetration into eggs after being washed with quat and sodium hypochlorite. In another study, Lucore et al. [20] asserted that a 3-log reduction of external shell bacteria after washing with a commercial egg wash detergent containing potassium hydroxide and potassium hypochlorite. A handful of studies have been conducted to challenge the efficacy of quaternary ammonium (quat) sanitizer against the microbial load on eggshells. Nonetheless, these studies did not extend to understanding the effect of quat on eggshell integrity during storage [21,22]. Hence, the present study intends to evaluate the microbial load of free-range and commercial farm shell eggs, the effect of quat sanitizer on the microbial load of free-range and farm shell eggs, and the external and internal microbial load of post-treatment free-range and commercial farm shell eggs.

\section{Materials and Methods}

\subsection{Sample Collection}

Two different brands of free-range shell eggs (one dozen) and two different brands of commercial farm shell eggs (one dozen) were purchased from a supermarket located in Mid Valley Megamall, Kuala Lumpur, Malaysia, and the 99 Speedmart retail store, Kuala Lumpur, Malaysia, including GPS locations (Table 1). The procurement from the different locations was due to stock availability. Only eggs free from apparent defects, cracks, and the latest expiry date were selected at purchase. The purchased samples were kept on ice in a polystyrene foam box during transportation to the Food Microbiology Teaching Lab, Faculty of Food Science and Technology, University Putra Malaysia, Selangor. The samples were immediately stored in a chiller $\left(4^{\circ} \mathrm{C}\right)$ upon arrival to the laboratory.

\subsection{Part 1: Eggshell Microbial Enumeration}

\subsubsection{Pre-Enrichment}

Whole free-range shell eggs ( $n=$ three) and commercial farm shell eggs $(n=$ three) from each brand were randomly selected from the egg tray and transferred into a sterile stomacher bag with autoclaved peptone water (0.1\%; Merck KGaA, Darmstadt, Germany). Shell egg rinsate was drained into a sterile beaker after gentle shaking for $5 \mathrm{~min}$. The rinsate was then pre-enriched in an incubator for $4 \mathrm{~h}$ at $35^{\circ} \mathrm{C}$ followed by a serial dilution up to $10^{-8}$. A similar procedure was repeated for four different brands of shell eggs (two free-range and two commercial farms). 
Table 1. Samples details.

\begin{tabular}{cccccc}
\hline Brand & Type & Oviposition Date & Producer Expiry Date & Purchase Date & $\begin{array}{c}\text { Purchase Location } \\
\text { (GPS) }\end{array}$ \\
\hline $\begin{array}{c}\text { A } \\
\text { Producer LH) } \\
\text { B }\end{array}$ & FR ${ }^{1}$ & 27 July 2018 & 25 August 2018 & 5 August 2018 & $3.117196,101.678054$ \\
$\begin{array}{c}\text { (Producer SS) } \\
\text { C }\end{array}$ & FR & Nil $^{3}$ & 19 November 2018 & 14 October 2018 & $3.117196,101.678054$ \\
$\begin{array}{c}\text { (Producer TS }) \\
\text { D }\end{array}$ & CF & 30 July 2018 & 29 August 2018 & 8 August 2018 & $3.117196,101.678054$ \\
$($ Producer LH) & CF & 20 August 2018 & 19 September 2018 & 21 August 2018 & $3.073501,101.673531$ \\
\hline
\end{tabular}

Note: ${ }^{1} \mathrm{FR}=$ free-range, ${ }^{2} \mathrm{CF}=$ commercial farm, ${ }^{3}$ Oviposition date data are not able to retrieve from the producer.

\subsubsection{Microbial Enumeration}

The microbial load analysis was carried out with a $100 \mu \mathrm{L}$ aliquot from the three highest dilutions pipetted into plate count agar (Oxoid CM0325, Hampshire, UK) in duplicate and incubated at $37^{\circ} \mathrm{C}$ for $24 \mathrm{~h}$ for a total aerobic mesophilic bacteria enumeration. The visible colonies formed were calculated as the logarithm of the colony-forming units per eggshell (Log10 CFU/eggshell). The enumeration procedure was carried out in triplicate. Similar procedures were repeated for Salmonella spp. enumeration on Xylose Lysine Deoxycholate Agar (XLD) (Oxoid CM0469, Hampshire, UK) and incubated at $37^{\circ} \mathrm{C}$ for 48 h; Coliform's enumeration was performed on desoxycholate agar (Oxoid CM0139, Hampshire, UK) and incubated at $28^{\circ} \mathrm{C}$ for $48 \mathrm{~h}$; yeasts and molds were performed on Potato Dextrose Agar (PDA) (Oxoid CM0139, Hampshire, UK) and incubated at $25^{\circ} \mathrm{C}$ for 5 days. MINITAB (Minitab, LLC, State College, PA, USA) application software (version 17) was used to analyze the mean population and variance (one-way ANOVA) between each brand.

\subsection{Part 2: Quaternary Ammonium Compound (Quat) Sanitizer Treatment}

\subsubsection{Pre-Washed Microbial Enumeration}

Free-range shell eggs ( $n=$ eight) and commercial farm shell eggs $(n=$ eight) were randomly selected for quat sanitizer treatment. Both free-range and commercial farm shell eggs were selected from the same producer in the interest of minimizing variation. Before treatment, the initial microbial count was carried out by swabbing $1 \mathrm{~cm}^{2}$ of the egg surface at three different spots using a sterile cotton bud. The bud was broken down and immersed into $10 \mathrm{~mL}$ of peptone water (Merck KGaA, Darmstadt, Germany) and vortexed. Microbial load analysis was carried out for total aerobic mesophilic bacteria, Salmonella spp., coliforms, yeasts, and molds.

\subsubsection{Quat Sanitizer Preparation}

Commercially available quat sanitizer (Quat Sanitizer Brand X, Sanawang, Malaysia) was prepared according to the manufacturer's recommended concentration for sanitizing unrinsed food contact surfaces, i.e., $1 \%(v / v)$ and $2 \%(v / v)$. $1 \mathrm{~mL}$ and $2 \mathrm{~mL}$ of quat sanitizer (5-10\% alkyl dimethyl benzyl ammonium chloride) were mixed with $1 \mathrm{~L}$ of distilled water (room temperature), respectively. The concentration of the quat sanitizer was verified using quat test paper (Micro Essential Laboratory, Kuala Lumpur, Malaysia) by matching it to the color scale. A $150 \mathrm{~mL}$ of $1 \%(v / v)$ and $2 \%(v / v)$ sanitizer were subsequently poured into eight sterile stomacher bags.

\subsubsection{Quat Sanitizer Treatment}

A full $\left(2^{2}\right)$ factorial experiment design was conducted with concentration as factor A (independent variable) and washing time as factor B (independent variable) as illustrated in Table 2. The shell eggs from the aforementioned "pre-wash microbial enumeration" 
procedure was placed into a stomacher bag filled with $100 \mathrm{~mL}$ of quat sanitizer (Quat

Sanitizer Brand X, Sanawang, Malaysia), respectively, and gently shaken and washed.

Table 2. Full $\left(2^{2}\right)$ factorial experiment design for the free-range egg quat sanitizer treatment.

\begin{tabular}{|c|c|c|c|c|c|}
\hline Shell Eggs Type & Egg-Laying Date & Producer Expiry Date & $n$ & $\begin{array}{c}\text { Factor A } \\
\text { (Concentration) }\end{array}$ & Factor B (Washing Time) \\
\hline \multirow{2}{*}{$\begin{array}{c}\text { Brand A } \\
\text { free-range eggs } \\
\text { (Producer LH) }\end{array}$} & 26 September 2018 & 26 October 2018 & $\begin{array}{l}2 \\
2 \\
2 \\
8\end{array}$ & $\begin{array}{l}100 \mathrm{ppm}, \mathrm{a}_{0} \\
100 \mathrm{ppm}, \mathrm{a}_{0} \\
200 \mathrm{ppm}, \mathrm{a}_{1} \\
200 \mathrm{ppm}, \mathrm{a}_{1}\end{array}$ & $\begin{array}{l}5 \mathrm{~min}, \mathrm{~b}_{0} \\
15 \mathrm{~min}, \mathrm{~b}_{1} \\
5 \mathrm{~min}, \mathrm{~b}_{0} \\
15 \mathrm{~min}, \mathrm{~b}_{1}\end{array}$ \\
\hline & 4 October 2018 & 4 November 2018 & $\begin{array}{l}2 \\
2 \\
2 \\
8\end{array}$ & $\begin{array}{l}100 \mathrm{ppm}, \mathrm{a}_{0} \\
100 \mathrm{ppm}, \mathrm{a}_{0} \\
200 \mathrm{ppm}, \mathrm{a}_{1} \\
200 \mathrm{ppm}, \mathrm{a}_{1}\end{array}$ & $\begin{array}{l}5 \min , b_{0} \\
15 \min , b_{1} \\
5 \min , b_{0} \\
15 \min , b_{1}\end{array}$ \\
\hline \multirow{2}{*}{$\begin{array}{c}\text { Brand D } \\
\text { commercial farm } \\
\text { shell eggs } \\
\text { (Producer LH) }\end{array}$} & 26 September 2018 & 26 October 2018 & $\begin{array}{l}2 \\
2 \\
2 \\
8\end{array}$ & $\begin{array}{l}100 \mathrm{ppm}, \mathrm{a}_{0} \\
100 \mathrm{ppm}, \mathrm{a}_{0} \\
200 \mathrm{ppm}, \mathrm{a}_{1} \\
200 \mathrm{ppm}, \mathrm{a}_{1}\end{array}$ & $\begin{array}{c}5 \mathrm{~min}, \mathrm{~b}_{0} \\
15 \mathrm{~min}, \mathrm{~b}_{1} \\
5 \mathrm{~min}, \mathrm{~b}_{0} \\
15 \mathrm{~min}, \mathrm{~b}_{1}\end{array}$ \\
\hline & 4 October 2018 & 4 November 2018 & $\begin{array}{l}2 \\
2 \\
2 \\
8\end{array}$ & $\begin{array}{l}100 \mathrm{ppm}, \mathrm{a}_{0} \\
100 \mathrm{ppm}, \mathrm{a}_{0} \\
200 \mathrm{ppm}, \mathrm{a}_{1} \\
200 \mathrm{ppm}, \mathrm{a}_{1}\end{array}$ & $\begin{array}{c}5 \mathrm{~min}, \mathrm{~b}_{0} \\
15 \mathrm{~min}, \mathrm{~b}_{1} \\
5 \mathrm{~min}, \mathrm{~b}_{0} \\
15 \mathrm{~min}, \mathrm{~b}_{1}\end{array}$ \\
\hline
\end{tabular}

When the washing time was up, the quat sanitizer was drained, and each treated egg surface was swabbed $1 \mathrm{~cm}^{2}$ from three different spots using a sterile cotton bud. The bud was broken down and immersed into $10 \mathrm{~mL}$ peptone water (Merck KGaA, Darmstadt, Germany) and vortexed. Microbial load analysis was carried out for total aerobic mesophilic bacteria, Salmonella spp., coliforms, yeasts, and molds.

\subsection{Part 3: Post-treatment Storage Microbial Study}

Commercial farm and free-range shell eggs treated with 200 ppm quat sanitizer for 15 min were selected for the post-treatment internal and external microbial load study. The main intention of such a selection was to investigate the vulnerability of the internal egg content toward vigorous washing with the highest permitted quat sanitizer concentration on the different types of shell eggs. Enumeration of total aerobic mesophilic bacteria, Salmonella spp., coliform, yeasts, and molds on both internal and external shell eggs were carried out at zero storage day. Treated shell eggs were then kept in a perforated stomacher bag (with small holes made from disinfected scissors with $75 \%$ alcohol) at room temperature and chilled temperature $\left(0-4{ }^{\circ} \mathrm{C}\right)$ for 15 days before the expiry date, and up until the expiry date (Table 3 ) for further microbial load analysis.

Table 3. Storage duration for the post-treatment microbial load study.

\begin{tabular}{|c|c|c|c|c|c|c|}
\hline Shell Eggs Type & Oviposition Date & Producer Expiry Date & $\begin{array}{l}\text { Microbial } \\
\text { Growth Study } \\
\text { on } 15 \text { Days } \\
\text { before the } \\
\text { Expiry Date }\end{array}$ & $n$ & $\begin{array}{c}\text { Microbial } \\
\text { Growth Study } \\
\text { on the Expiry } \\
\text { Date }\end{array}$ & $n$ \\
\hline $\begin{array}{l}\text { Brand A free-range egg } \\
\text { (Producer LH) }\end{array}$ & $\begin{array}{l}26 \text { September } 2018 \\
4 \text { October } 2018\end{array}$ & $\begin{array}{l}26 \text { October } 2018 \\
4 \text { November } 2018\end{array}$ & $\begin{array}{l}11 \text { October } 2018 \\
19 \text { October } 2018\end{array}$ & $\begin{array}{l}4^{1} \\
4^{1}\end{array}$ & $\begin{array}{l}26 \text { October } 2018 \\
4 \text { November } 2018\end{array}$ & $\begin{array}{l}4^{1} \\
4^{1}\end{array}$ \\
\hline $\begin{array}{l}\text { Brand D commercial farm } \\
\text { shell eggs (Producer LH) }\end{array}$ & $\begin{array}{c}26 \text { September } 2018 \\
4 \text { October } 2018\end{array}$ & $\begin{array}{c}26 \text { October } 2018 \\
4 \text { November } 2018\end{array}$ & $\begin{array}{l}11 \text { October } 2018 \\
19 \text { October } 2018\end{array}$ & $\begin{array}{l}4^{1} \\
4^{1}\end{array}$ & $\begin{array}{c}26 \text { October } 2018 \\
4 \text { November } 2018\end{array}$ & $\begin{array}{l}4^{1} \\
4^{1}\end{array}$ \\
\hline
\end{tabular}

Note ${ }^{1}$ Two samples from room temperature storage and two samples from chill temperature storage. 


\section{Result and Discussion}

\subsection{Part 1: Eggshell Microbial Load}

Total Aerobic Mesophilic Bacteria

The recovery of microbial load from free-range and commercial farm eggshell surfaces is illustrated in Table 4. Both brand A and B free-range shell eggs' total aerobic mesophilic bacteria count were found to be more significant $(p<0.05)$ than brand $C$ and $D$ commercial farm shell eggs in 1 to $3 \log 10 \mathrm{CFU} /$ shell egg. The highest bacteria count was $10 \log 10 \mathrm{CFU} /$ shell eggs recovered from brand A free-range shell eggs, whereas the lowest count was $7 \log 10 \mathrm{CFU} /$ shell eggs recovered from brand D commercial farm shell eggs. Likewise, the aerobic mesophilic bacteria recovered from eggshells reported by several researchers fell within 5 to $8 \log 10 \mathrm{CFU} /$ shell eggs $[5,23,24]$. The differences in the aerobic mesophilic bacteria range between individual researchers can be ascribed to the different egg's laying environment, including microbial level in the air and dust from the cage and the cleanliness of the packing area [5,12]. The study of Parisi et al. [23] elaborated that those free-range eggs tend to have more prolonged contact with hens after oviposition. Therefore, shavings of feces from hens could be a source of contamination.

Table 4. Eggshell microbial load: mean \pm SD of triplicate samples.

\begin{tabular}{ccccccc}
\hline \multirow{2}{*}{ Brand/Producer } & Type & \multicolumn{4}{c}{ Mean Population (log10 CFU/Shell Egg) } \\
\cline { 2 - 6 } & Free-range shell egg & $\begin{array}{c}\text { Total Aerobic } \\
\text { Mesophilic Bacteria }\end{array}$ & Salmonella & Coliforms & Yeasts & Molds \\
\hline A/Producer LH & $10.21 \pm 0.27^{\mathrm{a}}$ & ND $^{1}$ & ND & $6.96 \pm 0.43^{\mathrm{a}}$ & $2.00 \pm 3.46^{\mathrm{a}}$ \\
\hline B/Producer SS & Free-range shell egg & $8.86 \pm 0.25^{\mathrm{b}}$ & ND & ND & $6.21 \pm 0.28^{\mathrm{a}}$ & $7.16 \pm 0.56^{\mathrm{a}, \mathrm{b}}$ \\
\hline C/Producer TS & Commercial farm shell egg & $7.94 \pm 0.21^{\mathrm{c}}$ & $\mathrm{ND}$ & $\mathrm{ND}$ & $6.90 \pm 0.45^{\mathrm{a}}$ & $4.39 \pm 0.27^{\mathrm{b}}$ \\
\hline D/Producer LH & Commercial farm shell egg & $6.94 \pm 0.49^{\mathrm{d}}$ & ND & ND & $2.74 \pm 0.41^{\mathrm{b}}$ & $0.51 \pm 0.88^{\mathrm{a}}$ \\
\hline
\end{tabular}

Note: ${ }^{a-d}$ Values within the same column without a common superscript are significantly different $(p<0.05),{ }^{1}$ ND No detectable survivor cells by a direct plating procedure.

Plate count agar used in the current study for bacteria enumeration was non-selective and non-inhibitory, allowing a wide range of bacteria cells to be grown on the media. Hence, various colony phenotypes (dimension, color, shape, etc.) were observed on the agar plate, as shown in Figure 1. At least five different types of colony phenotypes were observed in the current study, as shown in Figure 1. Furthermore, each brand was observed with different colony phenotypes, and brand $\mathrm{D}$ was observed with two different colony phenotypes on the same agar. This indicates that there might be at least 5 different strains of aerobic mesophilic bacteria present on eggshells. In a study, Chaemsanit et al. [24] exanimated 16 eggs from markets and discovered 116 aerobic mesophilic bacteria strains that belonged to 15 different genera: Staphylococcus spp., Micrococcus spp., Enterococcus spp., Streptococcus spp., Bacillus spp., Corynebacterium spp., Acinetobacter spp., Neisseria spp., Salmonella spp., Proteus spp., Citrobacter spp., Escherichia coli, Klebsiella spp., Enterobacter spp. and Serratia spp., Streptococcus spp. and Micrococcus spp. were the predominant genus' amongst the isolates.

\subsection{Salmonella spp. and Coliforms}

On the contrary, Salmonella spp. and coliforms were undetected after $4 \mathrm{~h}$ pre-enrichment, on neither the free-range nor commercial farm shell eggs surface. Thus, even though the Salmonella prevalence is habitually linked to poultry and poultry-related products (as discussed in the literature review), the result of the current study may provide a discrete perspective of Salmonella contamination. This finding is inconsonant with Loongyai et al. [25], who asserts no observation of any Salmonella present on eggshell in a study of Salmonella prevalence from different laying hen housing systems located in Thailand. Similarly, a study by Ong et al. [26], observed that merely 10 out of 320 eggs (3.1\%) were 
Salmonella spp.-positive in a study of Salmonella prevalence on a Malaysia poultry farm. Alongside this, Jones et al. [27] claim that the coliforms level is merely 0.64 Log CFU/mL from a conventional cage laying system. Thus, the contamination was constantly lower than the free-range system, where eggs were either in contact directly with the floor (dirt and grass) or the nest box. The authors also emphasize that floor contact was the primary source of coliforms contamination of the eggshell. In addition, eggshell microflora is also closely associated with geographical areas [28]. Thus, the absence of coliforms and Salmonella in the current study may indicate that both free-range and commercial farm shell eggs have minimum contact with the dirty floor with good husbandry practice in place.

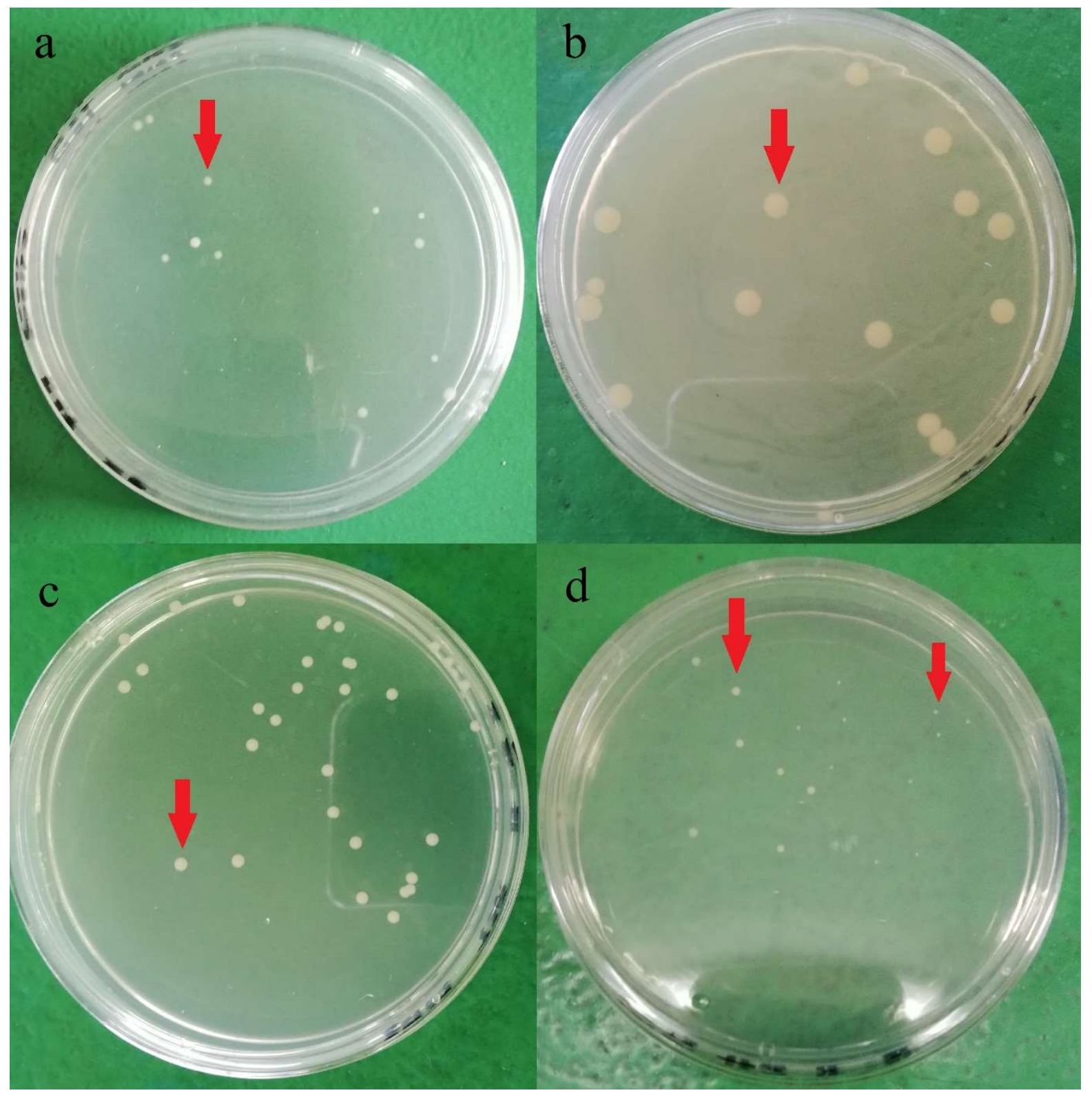

Figure 1. Different aerobic mesophilic bacteria colonies (red arrow) observed on plate count agar after $24 \mathrm{~h}$ incubation at $37^{\circ} \mathrm{C}$ from a different brands of shell eggs: (a) brand A, (b) brand B, (c) Brand C, (d) Brand D. 


\subsection{Yeasts and Molds}

The yeasts and molds population recovered from both free-range and commercial farm shell eggs are shown in Table 4 . The yeasts population for both free-range and commercial farm shell eggs ranged between 2.74 to $6.96 \log 10 \mathrm{CFU} /$ shell egg. However, there was no systematic trend observed when compared to the total aerobic mesophilic bacteria. An identical finding was reported by Jones and Anderson [29], where no significant difference of the yeast and mold populations were found in conventional cage and free-range nest box. The yeasts population from brand A and B free-range shell eggs appeared to have no significant difference $(p>0.05)$ with brand $C$ commercial farm shell eggs. In contrast, brand D's yeast population was peculiarly low $(p<0.05)$ with merely $2.7 \log 10 \mathrm{CFU} /$ shell egg. Brand A yeasts population (as with its aerobic bacteria count) had the highest yeasts contamination, i.e., $6.9 \log 10 \mathrm{CFU} / \mathrm{shell}$ egg amongst all brands.

The highest mold population of $7.2 \log 10 \mathrm{CFU} /$ shell eggs had been recovered from brand B free-range shell eggs. The prevalence of mold on eggshells is one of the deleterious factors that can cause the penetration of bacteria into the egg content. Molds' hyphae on eggshell surfaces facilitate the enlargement of shell pores after ovulation which ease the entry of bacteria into the content of the eggs [28]. Brand D commercial farm shell eggs had the lowest mold population with merely $0.51 \log 10 \mathrm{CFU} / \mathrm{shell}$ egg. On the other hand, the mold population of brand $\mathrm{C}$ commercial farm shell eggs was approximately $2 \log 10 \mathrm{CFU} /$ shell egg, significantly $(p<0.05)$ higher than the brand A free-range shell eggs. Likewise, the mold population between free-range and commercial farm shell eggs did not portray any systematic trend.

In terms of strain varieties, more than 14 different yeast and mold colony phenotypes were identified in the current study, and the colonies' appearance is shown in Figure 2. In a study, Musgrove et al. [30] identified 380 yeast genus or species from eggshells which included Candida, Cryptococcus, Hansenula, Hyphopichia, Metschnikowia, Rhodotorula, Sporobolomyces, and Torulaspora. Almost 85\% of the isolates (321 out of 380) were identified as Candida spp. Candida famata was the most identified species $(n=120)$, followed by Candida lusitaniae $(n=38)$. The authors also claimed that those identified yeast strains were generally non-infectious; however, some may cause opportunistic infections in immunocompromised individuals. Rajmani et al. [31] successfully isolated 129 molds from eggshells, and the isolated species belonged to six genera: Aspergillus, Penicillium, Fusarium, Mucor, Rhizopus, and Alternaria. Aspergillus (38.5\%) was found the be predominant, followed by Rhizopus (20.51\%), Mucor (11.28\%), Penicillium (9.23\%), Alternaria (6.66\%), and Fusarium (6.66\%).

\subsection{Part 2: Efficacy of Quat Sanitizer Free-range and Commercial Farm Shell Eggs Microbial Load Reduction}

Given the fact that the quat efficacy (microbial reduction) in both free-range and commercial farm shell eggs resembled due to similar treatment (same factor levels), thus the microbial log reduction (response) from both free-range and commercial farm shell eggs was integrated for data analysis. Figure 3 illustrates each factor level's response (after data integration of both free-range and commercial farm shell eggs). Figures 4-6 illustrate the comparisons of log reduction between free-range and commercial farm shell eggs, whereas Figure 7 illustrates the microbial colonies before and after treatment. The efficacy of quat sanitizer, in summary, significantly reduced approximately $4 \log 10 \mathrm{CFU} / \mathrm{cm}^{2}$ of the aerobic mesophilic bacteria to an acceptable level i.e., less than $6 \log 10 \mathrm{CFU} / \mathrm{cm}^{2}$; significantly reduced approximately 1.5 to $2.5 \log 10 \mathrm{CFU} / \mathrm{cm}^{2}$ of molds population to an un-detected level; significantly reduced (except free-range shell eggs) approximately 1.5 to $2 \log 10 \mathrm{CFU} / \mathrm{cm}^{2}$ of yeasts population to an un-detected level. Neither Salmonella nor coliforms were observed during pre- and post-quat sanitizer treatment. This result signifies the sanitation of shell eggs using 100 to $200 \mathrm{ppm}$ quat sanitizer prior to processing of any non-cook or non-baked food/desserts, e.g., raw eggs mayonnaise, custard, mousses, etc., for the foodservice industry, could minimize food poisoning probability caused by shell egg contamination. Concerning the antifungal efficacy, the current study finding 
concurred with Bernardi et al. [32], whereby quat sanitizer exhibited a significant impact on molds, but yeasts seemed less susceptible. The authors reported that 2 to $2.9 \log 10$ of Penicillium roqueforti, Penicillium commune and Aspergillus brasiliensis were observed after washing with a $2.5 \%$ quat sanitizer. Candida albicans was least susceptible to the quat sanitizer, whereby only a 1 to $1.9 \log 10$ reduction had been observed. In another study, Bundgaard-Nielsen and Nielsen [33] demonstrated that a $2 \%$ quat sanitizer successfully reduced 2 to $4 \log 10 \mathrm{CFU} / \mathrm{mL}$ of Penicillium, Cladosporium, and Scopulariopsis, Aspergillus and Eurotium, Neosartorya pseudofischeri, and Monascus ruber with a few exception strains that reduced more than $4 \log 10 \mathrm{CFU} / \mathrm{mL}$. The antimicrobial properties of quat sanitizer are contributed to by the 12-14 alkyls chain length [34].

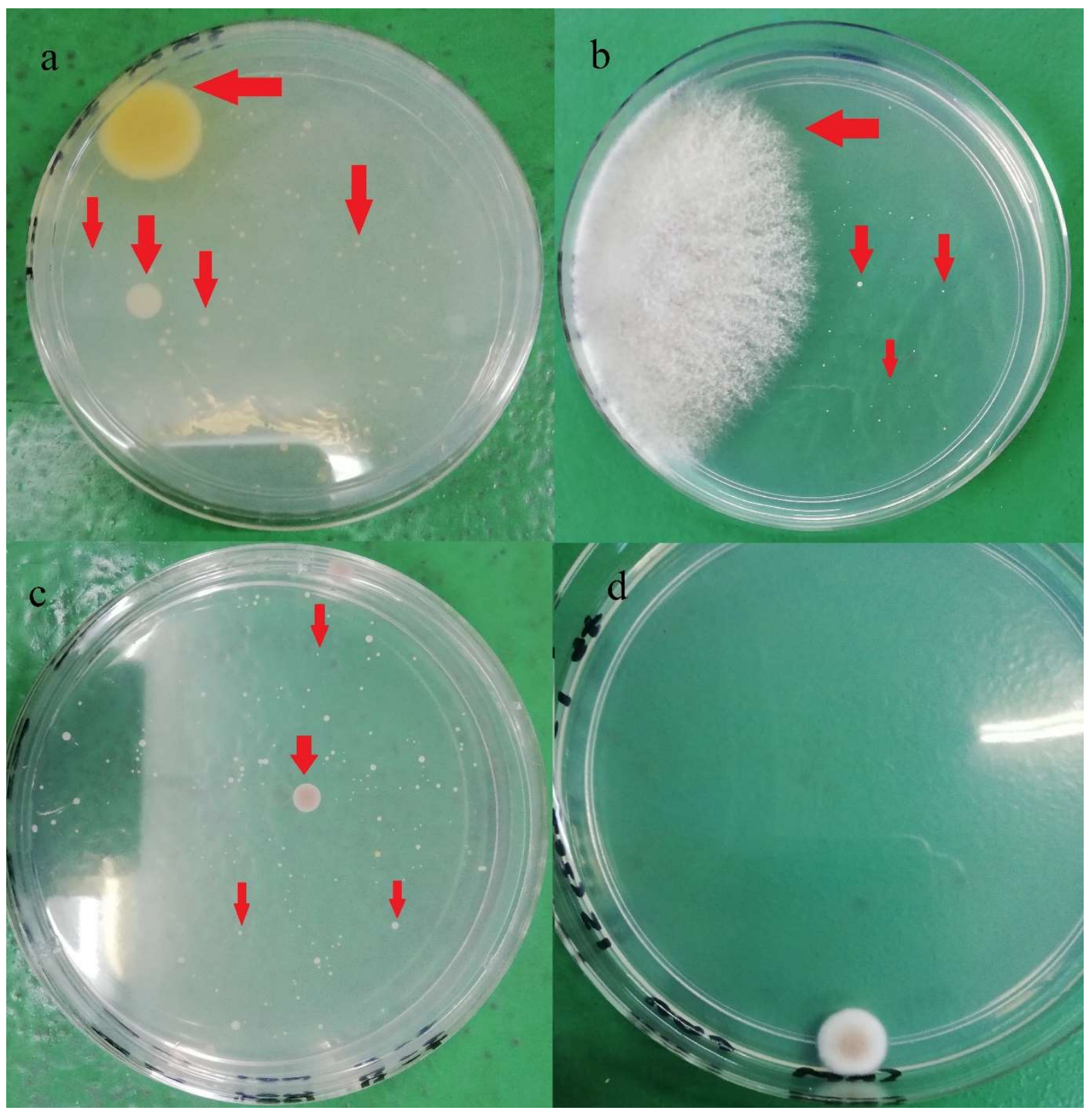

Figure 2. Different yeasts and molds colonies (red arrow) observed on PDA after five days incubation at $28^{\circ} \mathrm{C}$ : (a) brand A, (b) brand B, (c) Brand C, (d) Brand D. 


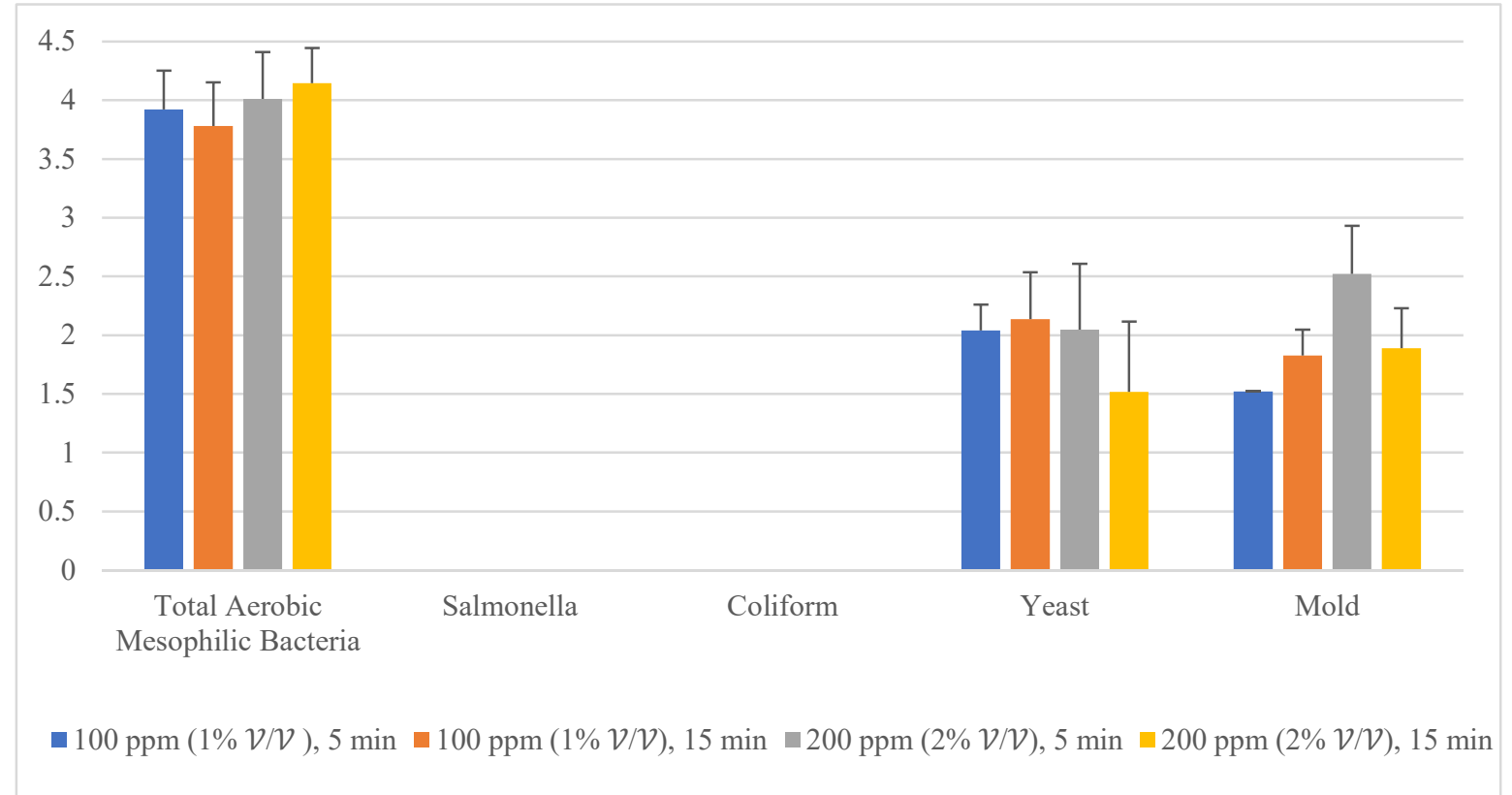

Figure 3. Total reduction of microbial $\operatorname{load}\left(\log 10 \mathrm{CFU} / \mathrm{cm}^{2}\right)$ after quat sanitizer treatment.

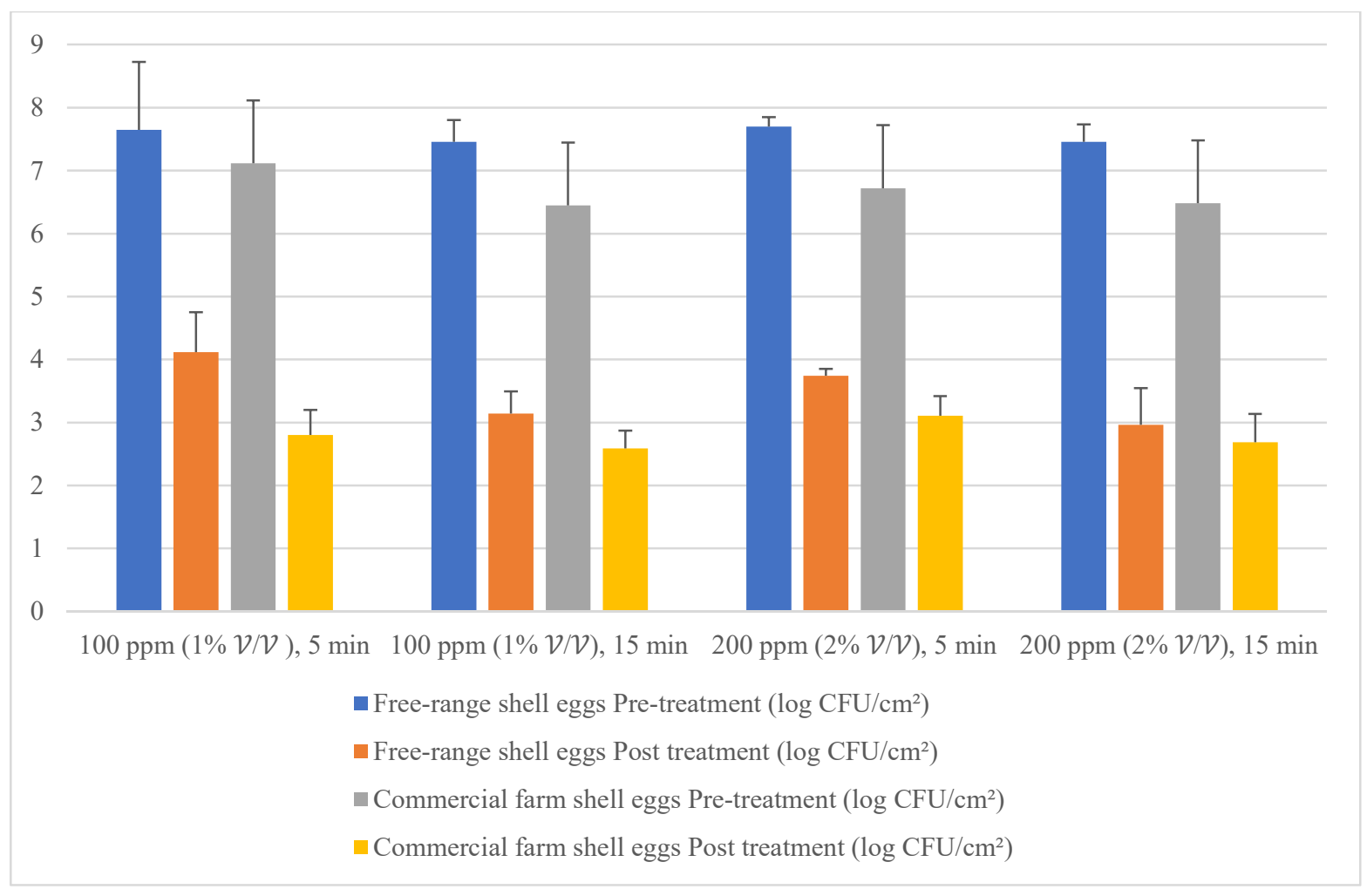

Figure 4. Mean population of aerobic mesophilic bacteria (pre- and post-treatment) for free-range shell eggs and commercial farm shell eggs. 


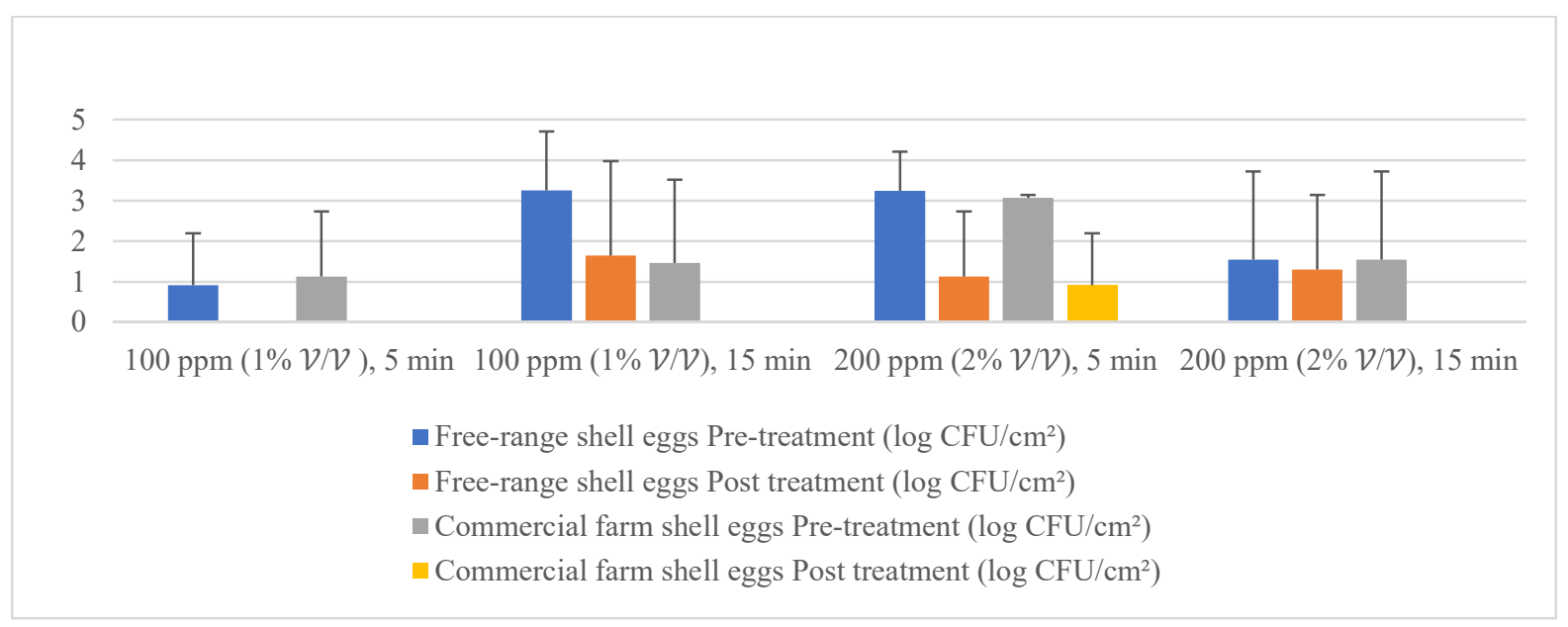

Figure 5. Mean population of yeasts (pre- and post-treatment) for free-range shell eggs and commercial farm shell eggs.

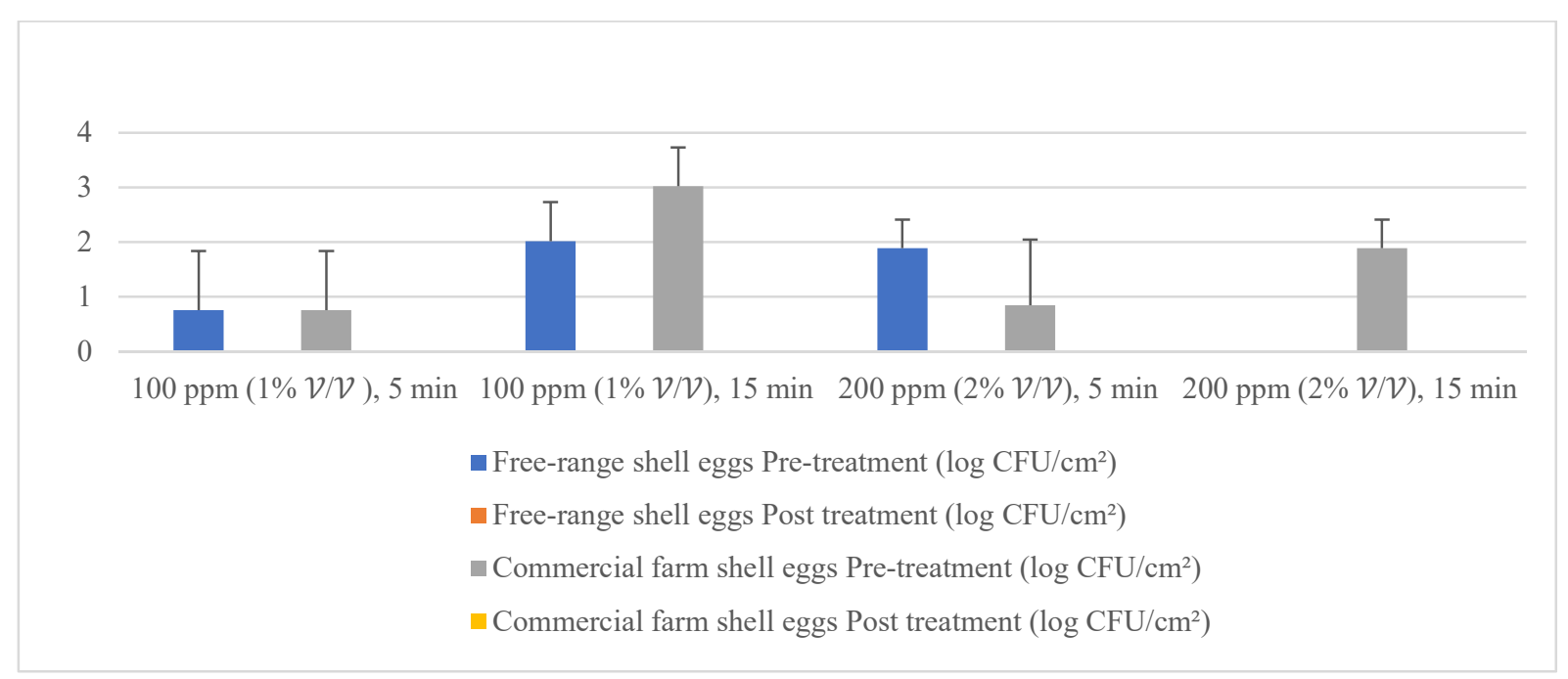

Figure 6. Mean population of molds (pre- and post-treatment) for free-range shell eggs and commercial farm shell eggs.

\subsection{Variable Interaction by Two-Way ANOVA}

The responses from each factor level were analyzed through a two-way ANOVA analysis. The four-combination factor level treatment significantly $(p<0.05)$ reduced the aerobic mesophilic bacteria. However, there was no significant $(p \geq 0.05)$ response observed between individual factor levels (maximum and minimum), and the two-way interaction terms were also not statistically significant $(p \geq 0.05)$. In addition, the relationship between each factor and the response may not depend on the value of the other factor. From the model summary, $\mathrm{R} 2=4.35 \%$ indicates that whenever a variation had been observed in the value of $\mathrm{y}$, only $4.35 \%$ of it is due to the model (or due to change in $\mathrm{x}$ ), and $95.65 \%$ is due to error or some unexplained factor. The regression equation in uncoded units is defined as $\mathrm{TPC}=4.15-0.00270$ Concentration -0.018 Time +0.000270 Concentration ${ }^{*}$ Time. Figure 8 illustrates the contour plot of the total aerobic mesophilic bacteria log reduction versus time and concentration. Likewise, each factor level and two-way interaction term for yeasts and molds population, illustrated in Figures 9 and 10, were not statistically significant $(p \geq 0.05)$. From the yeasts model summary, R2 $=16.73 \%$ indicates that whenever a variation had been observed in the value of y, only 16.73 of it is due to the model (or due to a change in $\mathrm{x}$ ), and $83.27 \%$ is due to error or some unexplained factor. The regression equation in uncoded units is defined as Yeasts $=-1.11+0.0187$ Concentration +0.203 Time -0.00151 Concentration ${ }^{*}$ Time. From the molds model summary, $\mathrm{R} 2=40.6 \%$ indicates that whenever 
a variation had been observed in the value of $y$, only $40.6 \%$ is due to the model (or due to a change in $\mathrm{x}$ ), and $59.4 \%$ is due to error or some unexplained factor. The regression equation in uncoded units is defined as Molds $=-1.82+0.0170$ Concentration +0.395 Time - 0.002185 Concentration*Time.

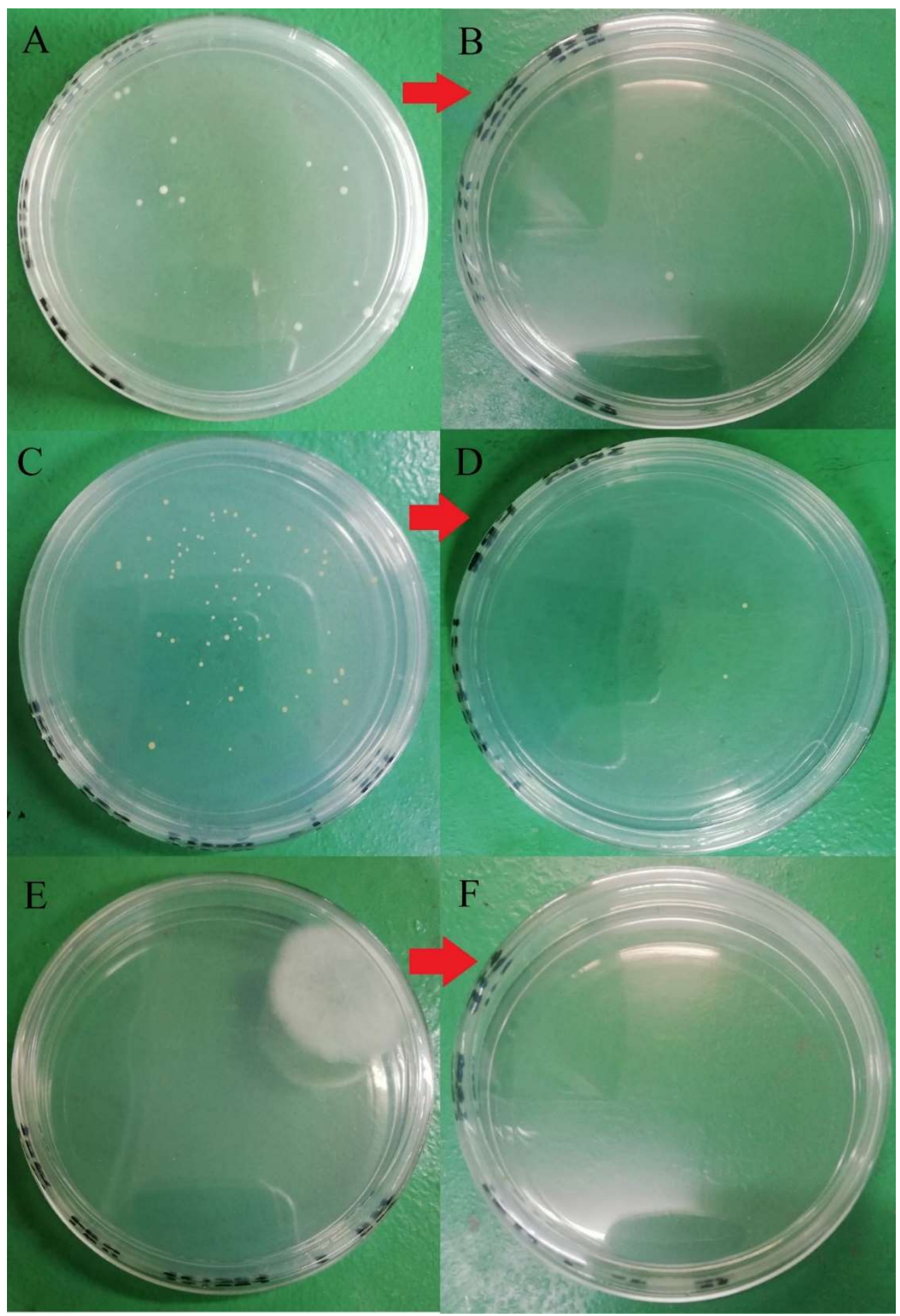

Figure 7. Microbial load before and after washing with $100 \mathrm{ppm}$ quat sanitizer for $5 \mathrm{~min}$. (A) Total aerobic mesophilic bacteria at a dilution of $10^{5}$ before washing; (B) total aerobic mesophilic bacteria at a dilution of $10^{3}$ after washing; (C) yeast population at a dilution of $10^{1}$ before washing; (D) yeasts population at a dilution of $10^{1}$ after washing; (E) molds population at a dilution of $10^{1}$ before washing; (F) molds population at dilution $10^{1}$ after washing. 


\section{Contour Plot of TPC log reduction vs Time, Concentration}
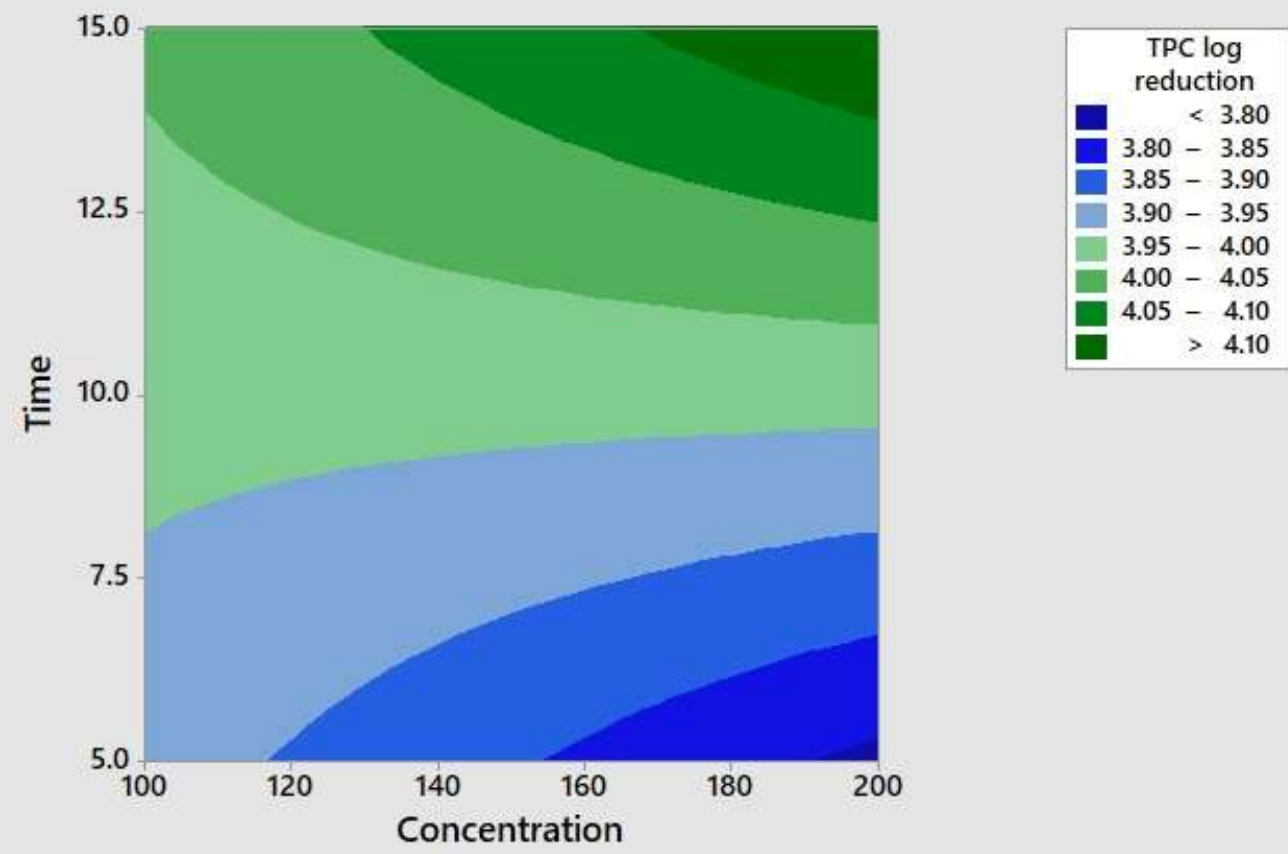

Figure 8. Contour plot of the total aerobic mesophilic bacteria logs reduction versus time and concentration.

\section{Contour Plot of Yeasts log reduction vs Time, Concentration}
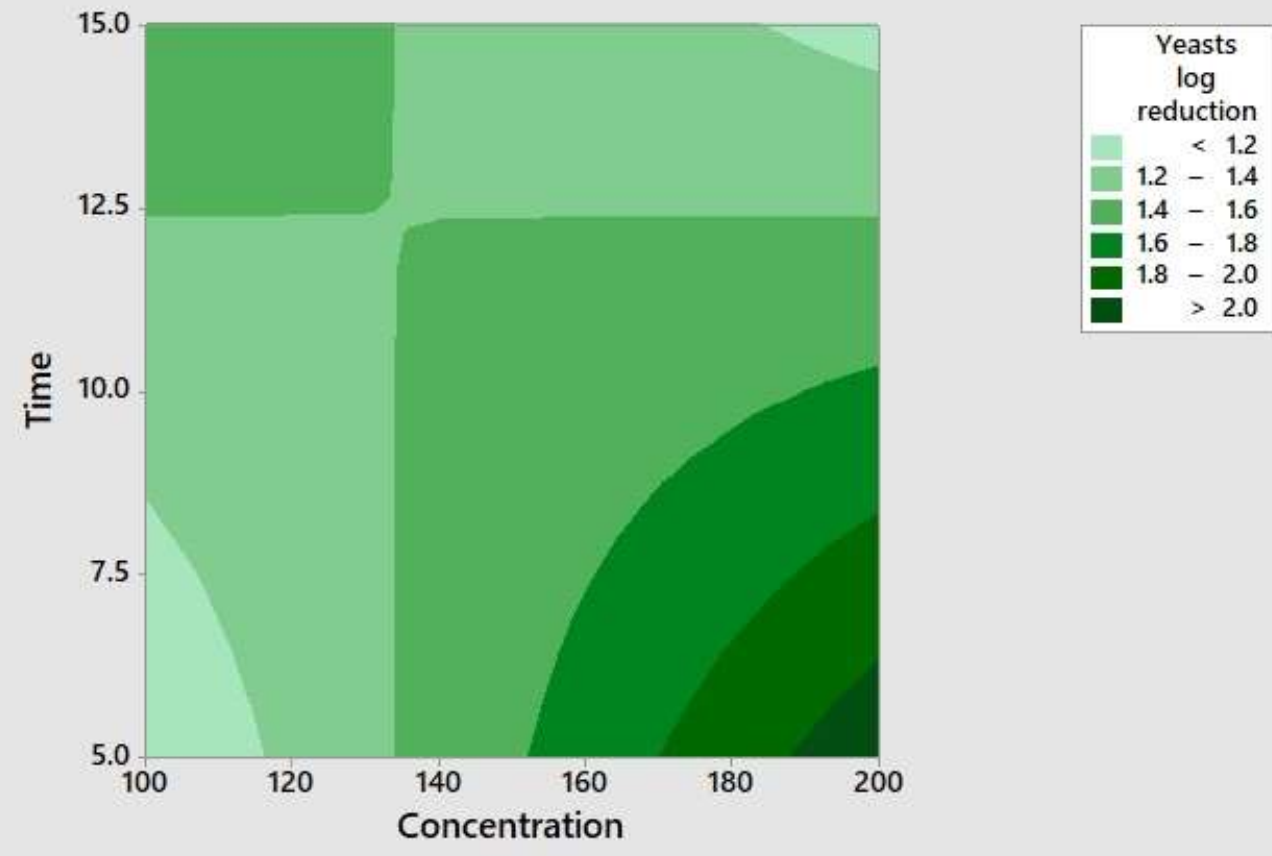

Figure 9. Contour plot of the yeasts logs reduction versus time and concentration. 


\section{Contour Plot of Molds log reduction vs Time, Concentration}
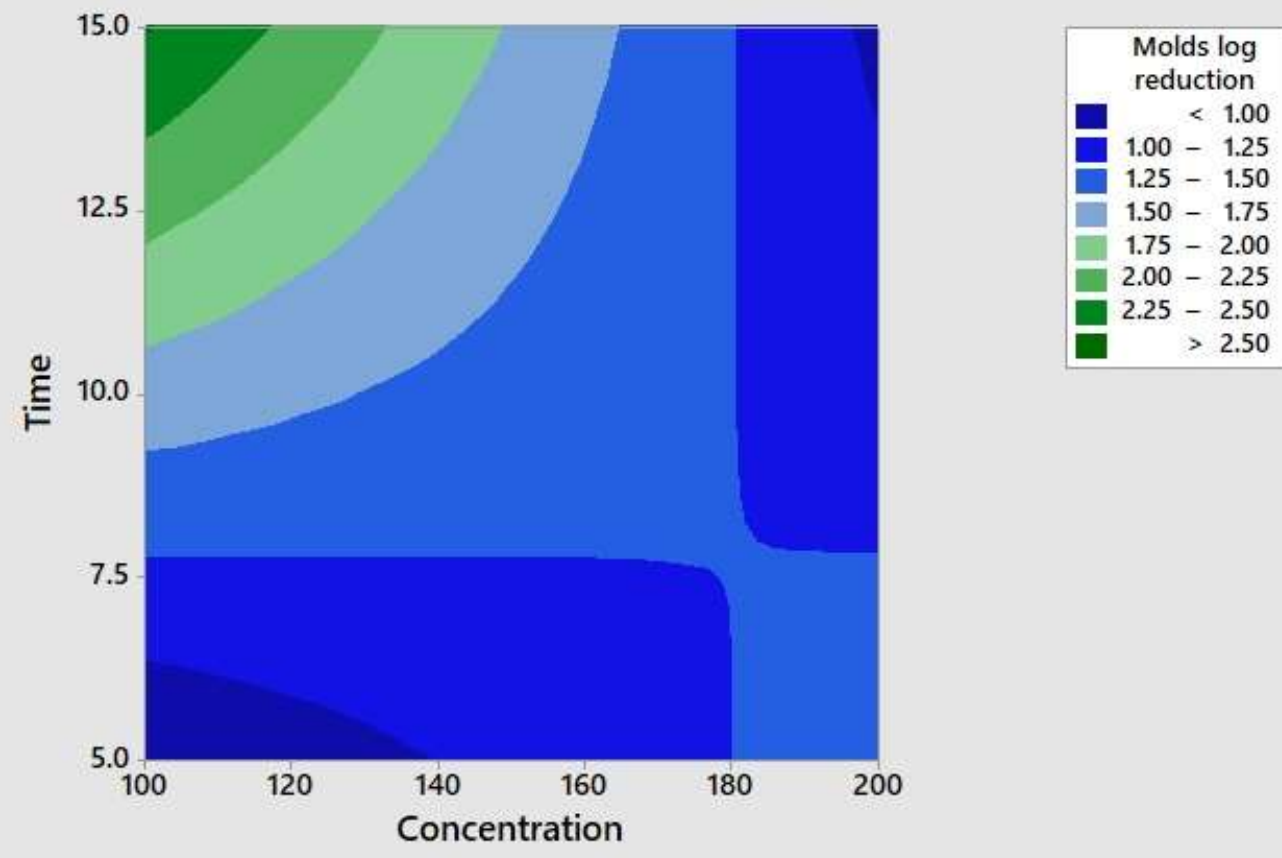

Figure 10. Contour plot of the molds logs reduction versus time and concentration.

The two-way ANOVA analysis outcome postulates that a higher concentration of quat sanitizer and washing time might be needed to observe significant log reduction. In a study, Bernardi et al. [32] demonstrated that no differences in fungi reduction were observed when the quat sanitizer concentration doubled from $2.5 \%$ to $5 \%$. In another study of fungi inhabitation, Tubajika [35] reported that 5 to $10 \%$ of fungi inhabitation had been observed only with a 10-fold increment of quat sanitizer concentration i.e., 100 to $1000 \mathrm{ppm}$. Even though the treatment period is considered a crucial factor in decreasing microbial load and heat treatment, e.g., pasteurization, autoclave, sterilization, etc., might not be the same in nonthermal treatment. The current study's finding shows no significant $(p \geq 0.05$ ) response was observed between the time factor level (maximum and minimum) and the two-way interaction terms with quat concentration. This explained no maximum exposure period required for the quat sanitizer to exhibit its efficacy but with a minimum of one minute of exposure as recommended by the producer on the labeling. Mustapha and Liewen [36] reported a similar finding that quat sanitizer successfully reduced more than $4 \log 10 \mathrm{CFU} / \mathrm{mL}$ of Listeria monocytogenes on a stainless-steel surface with low one-minute exposure.

\subsection{Negative Control}

Distilled water and dishwashing soap were used as a negative control in the current study to compare the quat sanitizer efficacy. The use of water and household dishwashing soap or laundry detergent to reduce eggshell microbial load can be traced back to the end of the 1940s [37]. Figure 11 illustrates the comparison of mean microbial reduction between quat sanitizer and both negative controls. Treatment duration (washing time) for the control study was identical to quat sanitizer $2^{2}$ experimental design, i.e., 5 min and $15 \mathrm{~min}$; however, no solution concentration differences were identified in the control study (only a single factor). The reduction trend of aerobic mesophilic bacteria was observed as being identical with the quat sanitizer treatment, i.e., bacteria was significantly $(p<0.05)$ reduced after being washed with distilled water and dishwashing soap. Nonetheless, the mean difference was observed as lesser compared with the quat sanitizer. 
Only approximately $2.6 \log 10 \mathrm{CFU} / \mathrm{cm}^{2}$ of aerobic mesophilic bacteria reduction had been observed after distilled water treatment, and only approximately 2 to $2.4 \log 10 \mathrm{CFU} / \mathrm{cm}^{2}$ of aerobic mesophilic bacteria had been observed after dishwashing soap treatment. This finding suggests that washing eggs with water and household dishwashing soap cannot reduce the microbial count to a safe limit i.e., $6 \log 10 \mathrm{CFU} / \mathrm{shell} \mathrm{egg.} \mathrm{Yeasts} \mathrm{and} \mathrm{molds}$ population, on the contrary, showed no observed significant reduction $(p \geq 0.05)$ after distilled water and dishwashing soap treatment.

$100 \mathrm{ppm}(1 \% \mathcal{V} / \mathcal{V})$ quat and 5 min washing for quat

$100 \mathrm{ppm}(1 \% \mathcal{V} / \mathcal{V})$ quat, and 15 min washing

200 ppm $(2 \% \mathcal{V} / \mathcal{V})$ quat with 5 min washing

$200 \mathrm{ppm}(2 \% \mathcal{V} / \mathcal{V})$ quat with 15 min washing

Control (washing 5 min with water)

Control (washing 15 min with water)

Control (washing 5 min with dish washer soap)

Control (washing 15 min with dish washer soap)

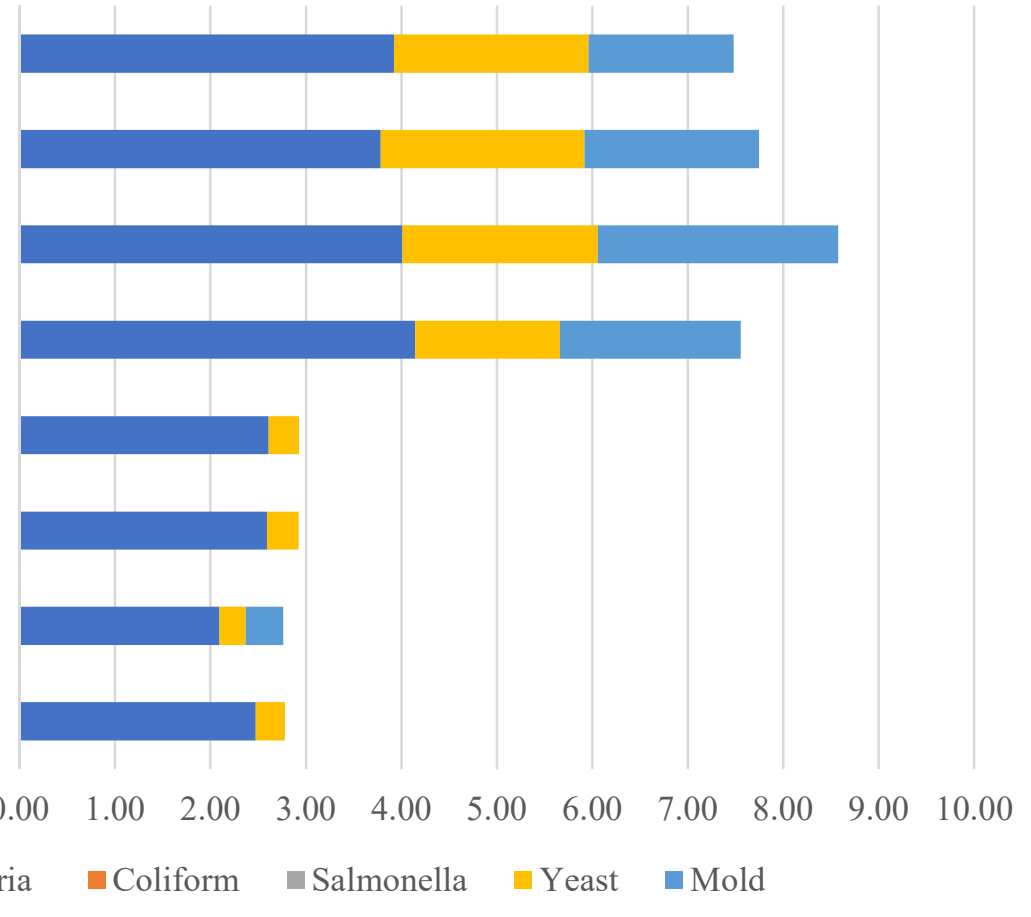

Figure 11. Comparison of the total reduction of microbial $\operatorname{load}\left(\log \mathrm{CFU} / \mathrm{cm}^{2}\right)$ after washing with quat, distilled water (control) and dishwashing soap (control).

\subsection{Part 3: Post-Treatment Storage Study}

\subsubsection{Eggshell Microbial Population}

Free-range and commercial farm shell eggs, which were washed with $200 \mathrm{ppm}$ quat sanitizer for $15 \mathrm{~min}$, were selected for the post-treatment external and internal microbial load study during the storage period up to the producer expiry date. Figure 12 illustrates the comparison of the external microbial load $\left(\log 10 \mathrm{CFU} / \mathrm{cm}^{2}\right)$ of free-range shell eggs during storage at room and chill temperature after being washed with $200 \mathrm{ppm}$ quat sanitizer for $15 \mathrm{~min}$. No statistical difference $(p \geq 0.05)$ was observed, at room temperature storage, for aerobic mesophilic bacteria and yeasts population along the storage period from post-treatment until 15 days before the producer's expiry date. Molds population, on the contrary, increased from non-detected levels to $2.1 \log \mathrm{CFU} / \mathrm{cm}^{2}$ along the storage period, from post-treatment until 15 days before the producer expiry date. When shell eggs were stored until the producer expiry date, the aerobic mesophilic bacteria population was astonishingly absent, but the yeasts increment and molds decrement were not statistically significant. Similar unsystematic trends were observed in cold storage $\left(0-4{ }^{\circ} \mathrm{C}\right)$ during the storage period. The incremental and decremental aerobic mesophilic bacteria population along the storage period from post-treatment up to the producer expiry date were not statistically significant $(p \geq 0.05)$. Yeasts population decreased to non-detected levels from $1.3 \operatorname{logs} \mathrm{CFU} / \mathrm{cm}^{2}$ after storage until 15 days before the producer expiry date in cold 
conditions. However, the population increased back to $2.3 \log 10 \mathrm{CFU} / \mathrm{cm}^{2}$ after storage until the producer expiry date. However, such an increment was not statistically different $(p \geq 0.05)$ with the post-treatment yeasts population. The molds population remained undetected after cold storage up 15 days before the producer expiry date. Nevertheless, the molds populations had increased to $2.2 \log 10 \mathrm{CFU} / \mathrm{cm}^{2}$ when shell eggs were stored until the producer expiry date.

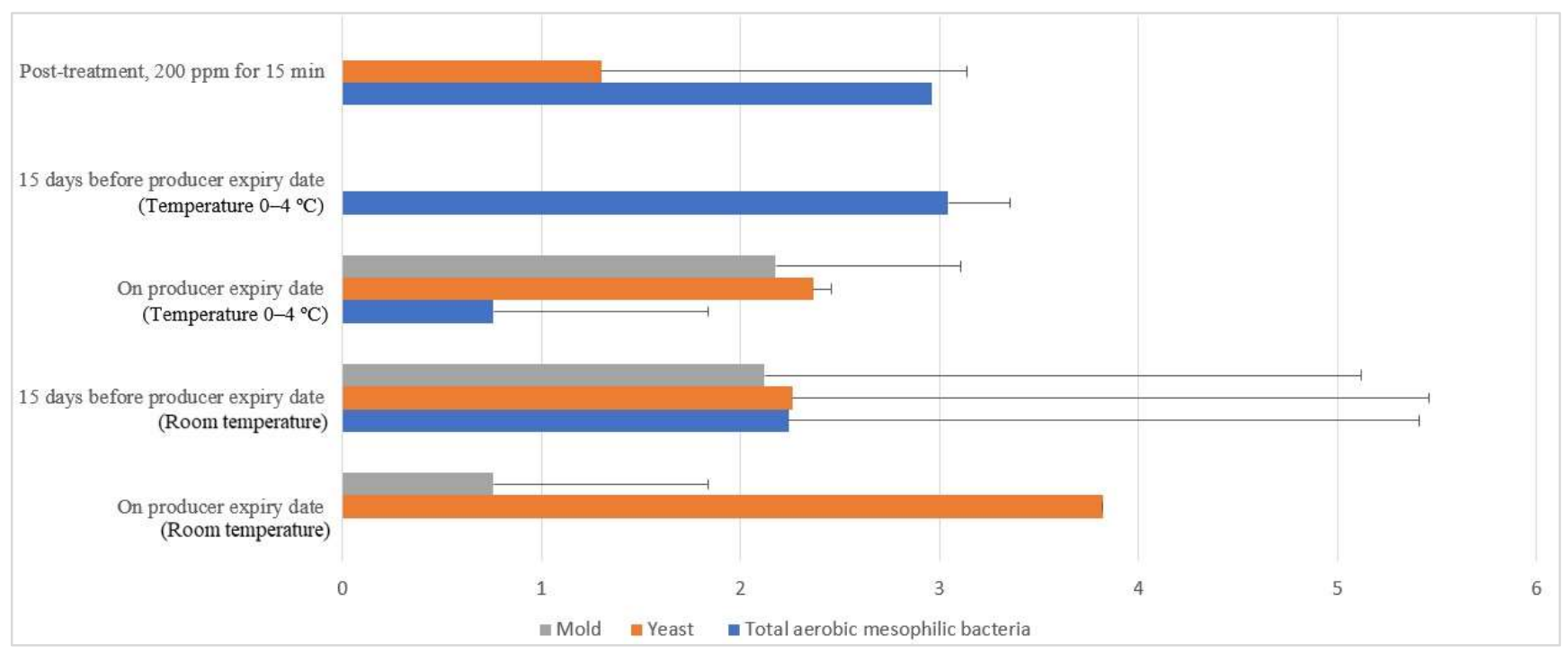

Figure 12. Comparison of the free-range eggshell microbial load $\left(\log 10 \mathrm{CFU} / \mathrm{cm}^{2}\right)$ during storage at room and chill temperature after washing with 200 ppm quat sanitizer for $15 \mathrm{~min}$.

Similar irregular trends were observed for the commercial farm shell eggs, and Figure 13 illustrates the comparison of the external microbial $\operatorname{load}\left(\log 10 \mathrm{CFU} / \mathrm{cm}^{2}\right)$ during storage at room and chill temperature after washing with $200 \mathrm{ppm}$ quat sanitizer $15 \mathrm{~min}$. No statistical difference $(p \geq 0.05)$ was observed for aerobic mesophilic bacteria along the storage period from post-treatment to the producer expiry date at room temperature. Yeasts and molds population, on the contrary, significantly increased from non-detected to $2.8 \log 10 \mathrm{CFU} / \mathrm{cm}^{2}$ and $2.4 \operatorname{logs} \mathrm{CFU} / \mathrm{cm}^{2} 15$ days before the producer expiry date, stored at room temperature. Further storage until the producer expiry date showed no statistically $(p \geq 0.05)$ significant increment for the yeasts population, but the molds population, on the contrary, had a statistically $(p<0.05)$ significant increment from 2.4 to $3.5 \log 10 \mathrm{CFU} / \mathrm{cm}^{2}$. In cold storage, aerobic mesophilic bacteria were observed as non-statistically $(p \geq 0.05)$ incremental along with the storage from post-treatment to 15 days before the producer expiry date. However, aerobic mesophilic bacteria were observed to decrease to un-detected from $2.7 \log 10 \mathrm{CFU} / \mathrm{cm}^{2}$ after storage up to the producer expiry date. No detection of any yeast population throughout the storage study at cold storage was made. Likewise, the molds population had not been detected after post-treatment and storage until 15 days before the producer expiry date. However, mild increments had been observed from non-detected to $0.8 \log 10 \mathrm{CFU} / \mathrm{cm}^{2}$ on the producer expiry date. 


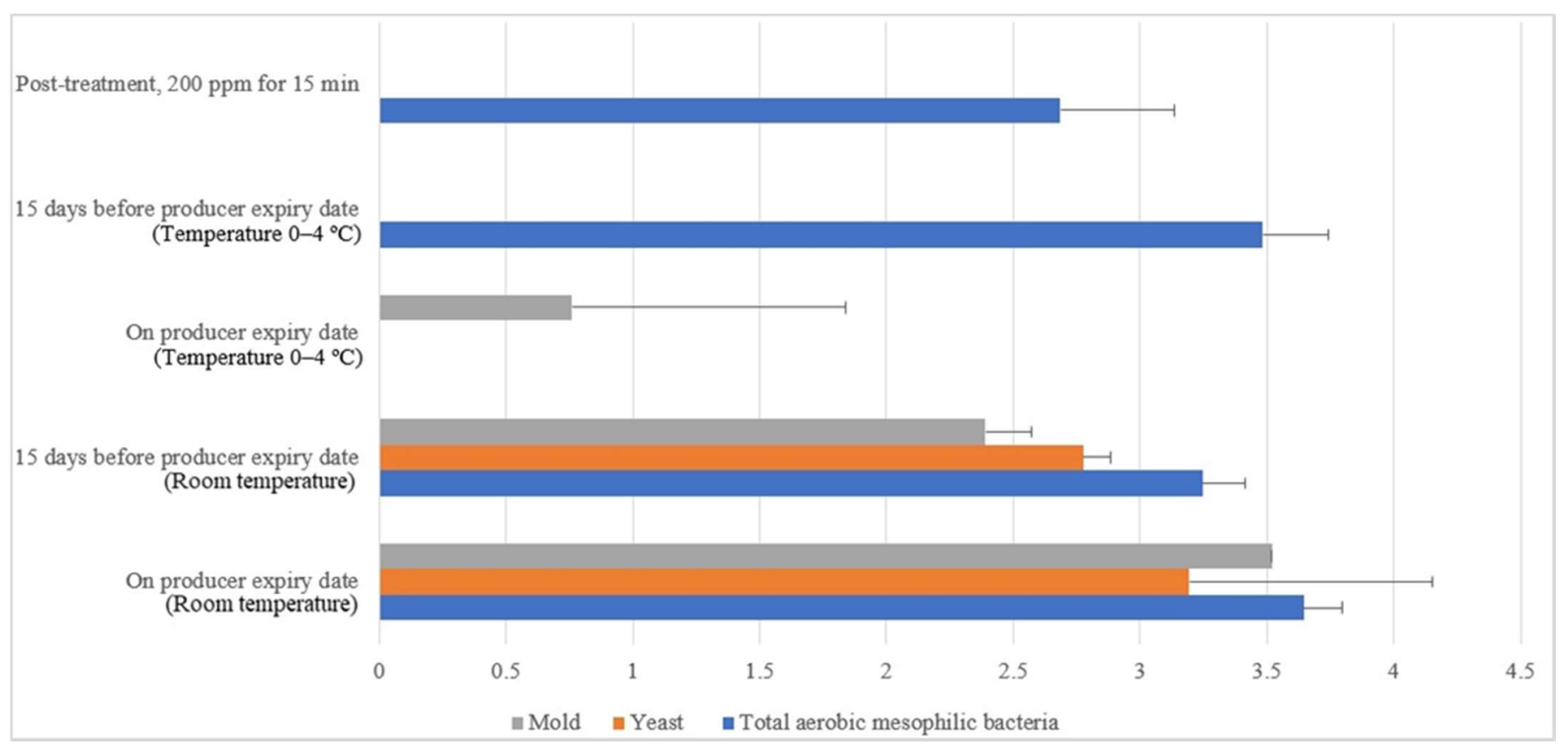

Figure 13. Comparison of commercial farm eggshell microbial load $\left(\log 10 \mathrm{CFU} / \mathrm{cm}^{2}\right)$ during storage at room and chill temperature after washing with 200 ppm quat sanitizer for $15 \mathrm{~min}$.

An irregular, extreme microbial trend observed from both the free-range and commercial farm shell eggs during the storage study might indicate complications from uncontrolled storage conditions. A similar low aerobic mesophilic bacteria trend was observed in commercial farm shell eggs stored in a cold environment up to the producer expiry date. Storage of shell eggs in cold storage may preserve its freshness and, more crucial, microbial control. An article on egg safety published by the US Food and Drug Administration [38] has educated the public to purchase shell eggs sold from a refrigerator or refrigerated case and store them promptly in a clean refrigerator at a temperature of $4{ }^{\circ} \mathrm{C}$ or below.

\subsubsection{Internal Microbial Population}

No microbial load was observed in both the free-range and commercial farm shell eggs' internal contents over the storage time at either room temperature or cold storage in the current study. Thus, the finding postulates that washing with the highest permissible quat concentration, i.e., $200 \mathrm{ppm}$ for $15 \mathrm{~min}$ discreetly (without physically damaging the eggshell) for both free-range and commercial farm shell eggs, will not facilitate microbial penetration during storage at either room temperature or cold storage. This finding is inconsistent with a study by Wang and Slavik [19] who demonstrated that quat sanitizer treatments did not damage the eggshell surface and reduced bacterial penetration for eggs stored for up to 21 days. In another study, Jones et al. [39] reported that aerobic bacteria were less than $1 \log 10 \mathrm{CFU} / \mathrm{mL}$ in egg content throughout the 10-week storage study at $4{ }^{\circ} \mathrm{C}$, and yeasts and molds population were less than $0.3 \log 10 \mathrm{CFU} / \mathrm{mL}$. The authors also illustrated that no significantly different egg content contamination between washed and unwashed shell eggs and eggs spoilage greatly depends on eggshell permeabilities [39].

Whether to wash and sanitize shell eggs remains an intensive debate in several countries, e.g., the United States of America, Japan, British, the European Union, etc. In the United States of America, all USDA-graded eggs and the largest volume processors are mandated to follow the washing step with a sanitizing rinse at the processing plant to minimize microbial contamination, especially Salmonella spp. [40]. Similar washing and sanitizing processes are also practiced by Japan; however, this practice remains elusive in Britain and the European Union for Class A eggs sold in the open market [37]. The lawmakers in the European Union reckon that washed eggs will cause moisture loss, pose 
damage to the physical barriers, such as the cuticle, and promote trans-shell contamination, thereby increasing the food safety risk to consumers if subsequent drying and storage conditions are not appropriate. Therefore, only authorized egg-washing systems to operate following the national guides are permissible to market washed eggs [41]. To recapitulate, egg sanitizing could render positive external microbial control during storage. Internal eggs content could be well preserved with the condition that appropriate sanitizer and washing systems are imposed.

\subsection{Part 4: Post-treatment Storage Negative Control \\ 3.8.1. Eggshell Microbial Population}

Commercial farm shell eggs underwent 15 min of distilled water treatment, and dishwashing soap treatment (washing) was selected for negative external and internal microbial load control study. Figure 14 illustrates the comparison of microbial load $\left(\log 10 \mathrm{CFU} / \mathrm{cm}^{2}\right)$ during storage at room and chill temperature after being washed with distilled water. The external aerobic mesophilic bacteria population increased non-statistically $(p \geq 0.05)$ along the storage period at room temperature up to the producer expiry date. Yeasts population had been observed to increase significantly $(p<0.05)$, approximately $0.9 \log 10 \mathrm{CFU} / \mathrm{cm}^{2}$ after storage for 15 days before the producer expiry date, and the population continued to increase another $0.4 \operatorname{logs} \mathrm{CFU} / \mathrm{cm}^{2}$ on the producer expiry date. Whereas for the molds population, an increase was observed from non-detected levels during post-treatment and 15 days before the producer expiry date to $2.2 \log 10 \mathrm{CFU} / \mathrm{cm}^{2}$ during producer expiry date. In cold storage, the aerobic mesophilic bacteria population dramatically decreased $(p<0.05)$ from $4.4 \log 10 \mathrm{CFU} / \mathrm{cm}^{2}$ to $0.8 \log 10 \mathrm{CFU} / \mathrm{cm}^{2} 15$ days before the producer expiry date but rebounded $(p<0.05)$ to $3.3 \log 10 \mathrm{CFU} / \mathrm{cm}^{2}$ on the producer expiry date. Yeast populations decreased statistically $(p<0.05)$ from $3.2 \log 10 \mathrm{CFU} / \mathrm{cm}^{2}$ to $2.5 \log 10 \mathrm{CFU} / \mathrm{cm}^{2}$ 15 days before the producer expiry date and further decreased to $1.1 \log 10 \mathrm{CFU} / \mathrm{cm}^{2}$ on the producer expiry date. Molds populations had not been observed throughout the storage study until the producer expiry date, i.e., $0.8 \log 10 \mathrm{CFU} / \mathrm{cm}^{2}$.

Post-treatment, distilled water washed for $15 \mathrm{~min}$

15 days before producer expiry date (Temperature $0-4^{\circ} \mathrm{C}$ )

On producer expiry date (Temperature $0-4{ }^{\circ} \mathrm{C}$ )

15 days before producer expiry date (Room temperature)

On producer expiry date (Room temperature)

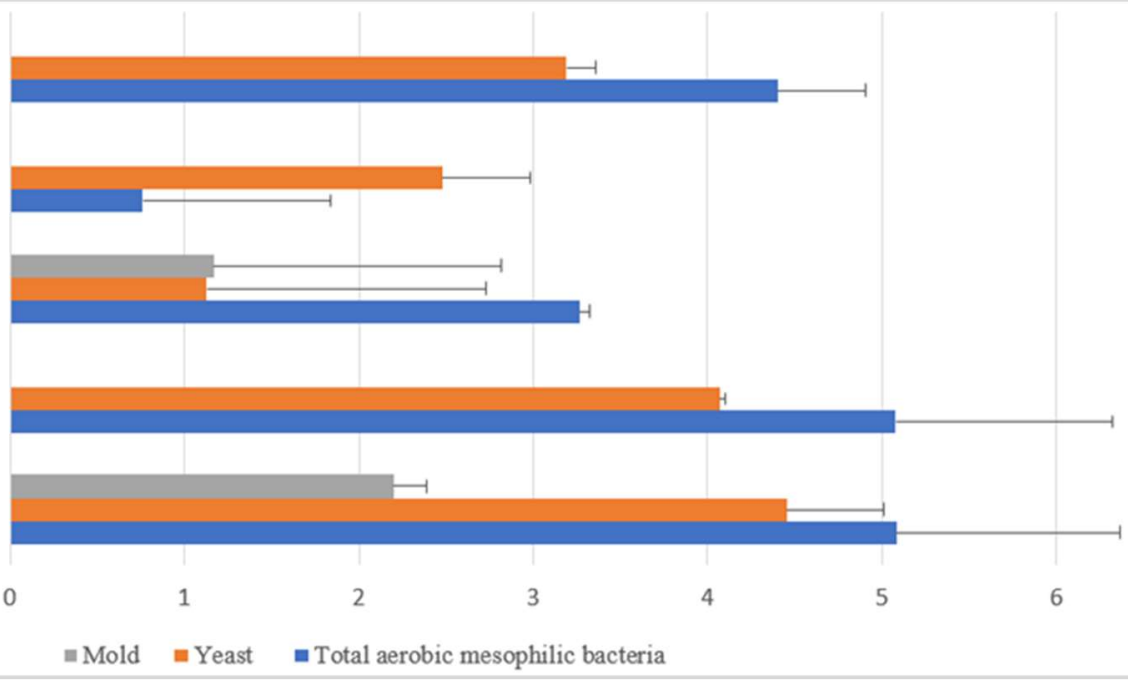

Figure 14. Microbial $\operatorname{load}\left(\log 10 \mathrm{CFU} / \mathrm{cm}^{2}\right)$ during storage at room and chill temperature washed with distilled water.

Figure 15 illustrates the comparison of the microbial load $\left(\log 10 \mathrm{CFU} / \mathrm{cm}^{2}\right)$ during storage at room and chill temperature after being washed with dishwashing soap. The external aerobic mesophilic bacteria population increased non-statistically $(p \geq 0.05)$ along the storage period at room temperature up to the producer expiry date. The yeasts population significantly increased $(p<0.05)$ approximately $2.3 \log 10 \mathrm{CFU} / \mathrm{cm}^{2}$ after storage for 15 days before the producer expiry, and the population were decreased approximately $0.9 \log 10 \mathrm{CFU} / \mathrm{cm}^{2}$ on the producer expiry date. Whereas for the molds population, an 
increase from un-detected levels during post-treatment and 15 days before the producer expiry date to $2.2 \log 10 \mathrm{CFU} / \mathrm{cm}^{2}$ during the producer expiry date was observed. In cold storage, the aerobic mesophilic bacteria population decreased dramatically $(p<0.05)$ from $4.3 \log 10 \mathrm{CFU} / \mathrm{cm}^{2}$ to $1.1 \log 10 \mathrm{CFU} / \mathrm{cm}^{2} 15$ days before the producer expiry date but rebounded $(p<0.05)$ to $3.5 \log 10 \mathrm{CFU} / \mathrm{cm}^{2}$ on the producer expiry date. Yeast populations decreased statistically $(p<0.05)$ from $2.9 \log 10 \mathrm{CFU} / \mathrm{cm}^{2}$ to $1.3 \log 10 \mathrm{CFU} / \mathrm{cm}^{2} 15$ days before the producer expiry date and further decreased to $0.8 \log 10 \mathrm{CFU} / \mathrm{cm}^{2}$ on the producer expiry date. The molds populations had not been observed throughout the storage study until on the producer expiry date, i.e., $1.2 \log 10 \mathrm{CFU} / \mathrm{cm}^{2}$. The fluctuation of the microbial count at both room temperature and cold storage might be due to the storage environment's complication.

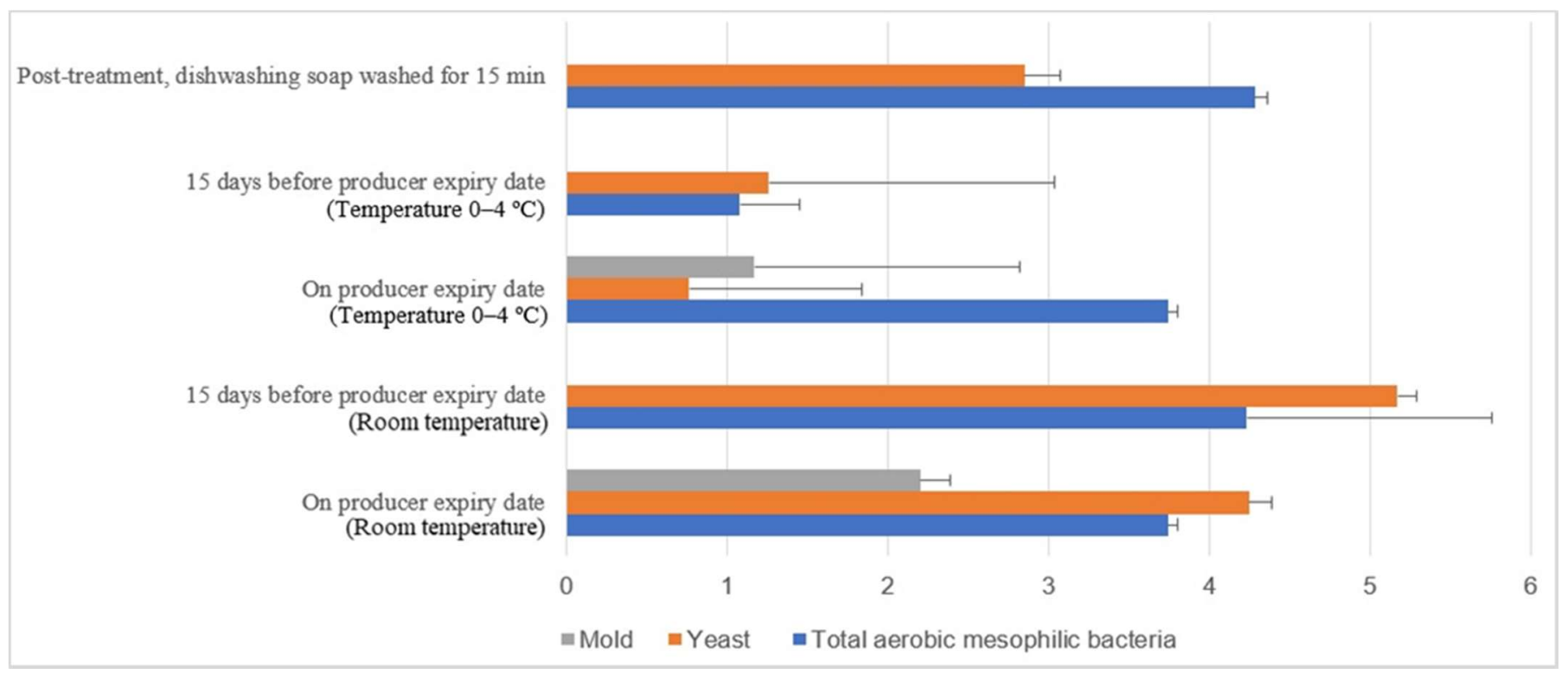

Figure 15. Microbial load $\left(\log 10 \mathrm{CFU} / \mathrm{cm}^{2}\right)$ during storage at room and chill temperature after washing with dishwashing soap.

\subsubsection{Internal Microbial Population}

No internal microbial load had been observed in both the distilled water treatment and dishwashing soap over the storage time at either room temperature or cold storage in the current study.

\section{Conclusions}

This study successfully demonstrated that two commercially available brands of freerange shell eggs' aerobic mesophilic bacteria count were 1 to $2 \log 10 \mathrm{CFU} /$ shell egg higher than two brands of commercial farm shell eggs. In addition, quat sanitizer had efficaciously reduced $4 \log 10 \mathrm{CFU} / \mathrm{cm}^{2}$ of the aerobic mesophilic bacteria; efficaciously reduced 1.5 to $2.5 \log 10 \mathrm{CFU} / \mathrm{cm}^{2}$ of the molds population to an un-detected level; efficaciously reduced (except free-range shell eggs) 1.5 to $2 \log 10 \mathrm{CFU} / \mathrm{cm}^{2}$ of the yeasts population to an undetected level. In addition, cold storage microbial load was observed as lower than room temperature storage along the storage period.

The current study indicates that washing and sanitizing shell eggs purchased from the open market is vital in minimizing food poisoning incidents due to shell eggs contamination, especially in preparing non-cooked/baked foods. Quat sanitizer with a maximum concentration of $200 \mathrm{ppm}$ is an effective alternative to minimize the microbial load yet is safe for non-rinse food contact. Purchased shell eggs should be stored in a cold en- 
vironment before ensuring microbial loads are under a safe level after sanitizing with quat sanitizer.

Nonetheless, the sampling size could be increased in future studies to cover most of the commercial brands available in Malaysia's open market. The impact on eggshell integrity after washing with quat sanitizer was demonstrated in the current study. However, a future improvement could be made by viewing the cross-section of the cuticle layer, the changes of egg yolk membrane integrity, the concentration of lysozyme and ovotransferrin over time due to washing, and prolonged storage. Also, comparison of various disinfectants e.g., hypochlorite, benzalkonium chloride, cetylpyridinium chloride, chlorhexidine, octenidine dihydrochloride, etc., could unravel the efficacy of microbial control of different sanitizers.

Author Contributions: Writing—original draft preparation, methodology, formal analysis, H.Y.C.; conceptualization, project administration, resources, funding acquisition, writing-review and editing, A.S.M.H.; supervision, Y.R., N.H.A., A.-E.F. All authors have read and agreed to the published version of the manuscript.

Funding: Funding was provided by the Faculty of Food Science and Technology of Universiti Putra Malaysia.

Institutional Review Board Statement: Not applicable.

Informed Consent Statement: Not applicable.

Data Availability Statement: Not applicable.

Conflicts of Interest: The authors declare no conflict of interest. The funders had no role in the study's design; in the collection, analyses, or interpretation of data; in the writing of the manuscript, or in the decision to publish the results.

Sample Availability: Samples of the compounds are not available from the authors.

\section{References}

1. Miranda, J.M.; Anton, X.; Redondo-Valbuena, C.; Roca-Saavedra, P.; Rodriguez, J.A.; Lamas, A.; Franco, C.M.; Cepeda, A. Egg and egg-derived foods: Effects on human health and use as functional foods. Nutrients 2015, 7, 706-729. [CrossRef]

2. Chickens and Eggs. Available online: https://www.nass.usda.gov/Publications/Todays_Reports/reports/ckeg1218.pdf (accessed on 15 February 2020).

3. The Federation of Livestock Farmers' Associations of Malaysia Table Egg Production. Available online: http://www.flfam.org. my/index.php/industry-info/the-poultry-industry/table-egg-production (accessed on 30 March 2018).

4. Malay Mail 'Puding Buih' Food Poisoning Case Due to Use of Expired Eggs, Says Terengganu Exco. Available online: https: / / www.malaymail.com/news/malaysia/2020/05/31/puding-buih-food-poisoning-case-due-to-use-of-expired-eggssays-terengganu/1871122 (accessed on 25 August 2020).

5. De Reu, K.; Grijspeerdt, K.; Heyndrickx, M.; Uyttendaele, M.; Debevere, J.; Herman, L. Bacterial shell contamination in the egg collection chains of different housing systems for laying hens. Br. Poult. Sci. 2006, 47, 163-172. [CrossRef]

6. Magdelaine, P. Trends in the European Poultry and Egg Market and the Impact of European Union Enlargement; CABI: Oxford, UK, 2006.

7. Miao, Z.H.; Glatz, P.C.; Ru, Y.J. Free-range poultry production-A review. Asian Australas. J. Anim. Sci. 2005, 18, 113-132. [CrossRef]

8. Daigle, C.; Siegford, J. Welfare Quality®parameters do not always reflect hen behaviour across the lay cycle in non-cage laying hens. Anim. Welf. 2014, 23, 423-434. [CrossRef]

9. Van De Weerd, H.A.; Keatinge, R.; Roderick, S. A review of key health-related welfare issues in organic poultry production. World's Poult. Sci. J. 2009, 65, 649-684. [CrossRef]

10. Ferrante, V.; Lolli, S.; Vezzoli, G.; Cavalchini, L.G. Effects of two different rearing systems (organic and barn) on production performance, animal welfare traits and egg quality characteristics in laying hens. Ital. J. Anim. Sci. 2009, 9, 165-174. [CrossRef]

11. Álvarez-Fernández, E.; Domínguez-Rodríguez, J.; Capita, R.; Alonso-Calleja, C. Influence of housing systems on microbial load and antimicrobial resistance patterns of Escherichia coli isolates from eggs produced for human consumption. J. Food Prot. 2012, 75, 847-853. [CrossRef]

12. Jones, D.R.; Anderson, K.E.; Musgrove, M.T. Comparison of environmental and egg microbiology associated with conventional and free-range laying hen management. Poult. Sci. 2011, 90, 2063-2068. [CrossRef]

13. Barbour, E.K.; El Jurdi, L.; Issa, C.; Tannous, R. Preliminary attempts towards production of table eggs free from Salmonella enteritidis. J. Clean. Prod. 2001, 9, 69-73. [CrossRef]

14. James, C.; Lechevalier, V.; Ketteringham, L. Surface pasteurisation of shell eggs. J. Food Eng. 2002, 53, 193-197. [CrossRef] 
15. Achiwa, N.; Nishio, T. The use of electrolyzed water for sanitation control of eggshells and GP center. Food Sci. Technol. Res. 2003, 9, 100-103. [CrossRef]

16. Favier, G.I.; Escudero, M.E.; Mattar, M.A.; De Guzmán, A.M.S. Survival of Yersinia enterocolitica and mesophilic aerobic bacteria on eggshell after washing with hypochlorite and organic acid solutions. J. Food Prot. 2000, 63, 1053-1057. [CrossRef]

17. Kim, C.; Hung, Y.C.; Brackett, R.E.; Lin, C.S. Efficacy of electrolyzed oxidizing water in inactivating salmonella on alfalfa seeds and sprouts. J. Food Prot. 2003, 66, 208-214. [CrossRef]

18. Worley, B.S.; Wheatley, W.B.; Lauten, S.D.; Williams, D.E.; Mora, E.C.; Worley, S.D. Inactivation of Salmonella enteritidis on shell eggs by novel N-halamine biocidal compounds. J. Ind. Microbiol. 1992, 11, 37-42. [CrossRef]

19. Wang, H.; Slavik, M.F. Bacterial penetration into eggs washed with various chemicals and stored at different temperatures and times. J. Food Prot. 1998, 61, 276-279. [CrossRef]

20. Lucore, L.A.; Jones, F.T.; Anderson, K.E.; Curtis, P.A. Internal and external bacterial counts from shells of eggs washed in a commercial-type processor at various wash-water temperatures. J. Food Prot. 1997, 60, 1324-1328. [CrossRef] [PubMed]

21. Al-Ajeeli, M.N.; Taylor, T.M.; Alvarado, C.Z.; Coufal, C.D. Comparison of eggshell surface sanitization technologies and impacts on consumer acceptability. Poult. Sci. 2016, 95, 1191-1197. [CrossRef] [PubMed]

22. Berrang, M.E.; Frank, J.F.; Buhr, R.J.; Bailey, J.S.; Cox, N.A.; Mauldin, J.M. Microbiology of sanitized broiler hatching eggs through the egg production period. J. Appl. Poult. Res. 1997, 6, 298-305. [CrossRef]

23. Parisi, M.A.; Northcutt, J.K.; Smith, D.P.; Steinberg, E.L.; Dawson, P.L. Microbiological contamination of shell eggs produced in conventional and free-range housing systems. Food Control 2015, 47, 161-165. [CrossRef]

24. Chaemsanit, S.; Akbar, A.; Kumar Anal, A. Isolation of total aerobic and pathogenic bacteria from table eggs and its contents. Food Appl. Biosci. J. 2015, 3, 1-9.

25. Loongyai, W.; Wiriya, B.; Sangsawang, N. Detection of Salmonella and Escherichia coll in egg shell and egg content from different housing systems for laying hens. Int. J. Poult. Sci. 2011, 10, 93-97. [CrossRef]

26. Ong, L.P.; Muniandy, K.; How, S.P.; Yip, L.S.; Lim, B. Salmonella isolation from poultry farms in Malaysia. Eterinary Res. 2014, 5, 65-68.

27. Jones, D.R.; Anderson, K.E.; Guard, J.Y. Prevalence of coliforms, Salmonella, Listeria, and Campylobacter associated with eggs and the environment of conventional cage and free-range egg production. Poult. Sci. 2012, 91, 1195-1202. [CrossRef]

28. Mayes, F.J.; Takeballi, M.A. Microbial Contamination of the Hen's Egg: A Review. J. Food Prot. 1983, 46, 1092-1098. [CrossRef]

29. Jones, D.R.; Anderson, K.E. Housing system and laying hen strain impacts on egg microbiology. Poult. Sci. 2013, 92, 2221-2225. [CrossRef]

30. Musgrove, M.T.; Jones, D.R.; Hinton, A.; Ingram, K.D.; Northcutt, J.K. Identification of yeasts isolated from commercial shell eggs stored at refrigerated temperatures. J. Food Prot. 2008, 71, 1258-1261. [CrossRef]

31. Rajmani, R.S.; Singh, A.P.; Singh, P.K.; Doley, J.; Verma, S.P. Fungal contamination in eggs. Indian Assoc. Vet. Public Heal. Spec. 2011, 9, 61-85.

32. Bernardi, A.O.; Stefanello, A.; Garcia, M.V.; Parussolo, G.; Stefanello, R.F.; Moro, C.B.; Copetti, M.V. Efficacy of commercial sanitizers against fungi of concern in the food industry. LWT 2018, 97, 25-30. [CrossRef]

33. Bundgaard-Nielsen, K.; Nielsen, P.V. Fungicidal effect of 15 disinfectants against 25 fungal contaminants commonly found in bread and cheese manufacturing. J. Food Prot. 1996, 59, 268-275. [CrossRef] [PubMed]

34. Buffet-Bataillon, S.; Tattevin, P.; Bonnaure-Mallet, M.; Jolivet-Gougeon, A. Emergence of resistance to antibacterial agents: The role of quaternary ammonium compounds-A critical review. Int. J. Antimicrob. Agents 2012, 39, 381-389. [CrossRef]

35. Tubajika, K.M. Efficacy of alkyl dimethyl benzyl ammonium chloride on suppression of Physalospora vaccinii in laboratory assays. J. Food Prot. 2006, 69, 2460-2464. [CrossRef]

36. Mustapha, A.; Liewen, M.B. Destruction of Listeria monocytogenes by Sodium Hypochlorite and Quaternary Ammonium Sanitizers. J. Food Prot. 1989, 52, 306-311. [CrossRef]

37. Hutchison, M.L.; Gittins, J.; Walker, A.; Moore, A.; Burton, C.; Sparks, N. Washing table eggs: A review of the scientific and engineering issues. Worlds. Poult. Sci. J. 2003, 59, 233-248. [CrossRef]

38. US Food and Drug Administration. Egg Safety: What You Need to Know; USFDA: Washington, DC, USA, 2021.

39. Jones, D.R.; Musgrove, M.T.; Northcutt, J.K. Variations in external and internal microbial populations in shell eggs during extended storage. J. Food Prot. 2004, 67, 2657-2660. [CrossRef]

40. Shell Eggs from Farm to Table. Available online: https://www.fsis.usda.gov/food-safety/safe-food-handling-and-preparation/ eggs/shell-eggs-farm-table (accessed on 25 August 2020).

41. Commission Regulation (EC) No 589/2008. Laying down Detailed Rules for Implementing Council Regulation (EC) No $1234 / 2007$ as Regards Marketing Standards for Eggs. Off. J. Eur. Union 2008, 51, 6-23. 